Article

\title{
Asymmetric Impacts of Oil Price on Inflation: An Empirical Study of African OPEC Member Countries
}

\author{
Umar Bala ${ }^{1,2}$ and Lee Chin ${ }^{2, *(D)}$ \\ 1 Department of Economics, Faculty of Management and Social Sciences, Bauchi State University, \\ P.M.B. 65 Gadau, Nigeria; umarbala@basug.edu.ng \\ 2 Department of Economics, Faculty of Economics and Management, Universiti Putra Malaysia, \\ 43400 UPM Serdang, Selangor Darul Ehsan, Malaysia \\ * Correspondence: leechin@upm.edu.my; Tel.: +60-603-8946-7769
}

Received: 14 August 2018; Accepted: 26 October 2018; Published: 2 November 2018

\begin{abstract}
This study investigates the asymmetric impacts of oil price changes on inflation in Algeria, Angola, Libya, and Nigeria. Three different kinds of oil price data were applied in this study: the actual spot oil price of individual countries, the OPEC reference basket oil price, and an average of the Brent, WTI, and Dubai oil price. Autoregressive distributed lag (ARDL) dynamic panels were used to estimate the short- and long-term impacts. Also, we partitioned the oil price into positive and negative changes to capture asymmetric impacts and found that both the positive and negative oil price changes positively influenced inflation. However, the impact was found to be more significant when the oil prices dropped. We also found that the money supply, the exchange rate, and the gross domestic product (GDP) are positively related to inflation, while food production is negatively related to inflation. Accordingly, policy-makers should be cautious when formulating policies between the positive and negative changes in oil prices, as it was shown that inflation increased when the oil price dropped. Additionally, the use of a contractionary monetary policy would help to reduce the inflation rate. Lastly, we suggest that the government should encourage domestic food production, both in quantity and quality, to reduce inflation.
\end{abstract}

Keywords: oil price; food production; inflation; asymmetric; Algeria; Angola; Libya; Nigeria

\section{Introduction}

During the 1970s, economies around the world experienced increasing inflation rates that were followed by a rapid rise in international crude oil prices. In contrast, the significant decrease in inflation that was experienced during the 1980s and 1990s was associated with falling oil prices in global markets [1]. However, despite the higher price for crude oil during the 2000s, this observation, in this case, suggests that inflation was lower in many countries when compared with the rising oil prices and inflation that were experienced during the 1970s [2]. That notwithstanding, the rise and decline in crude oil prices during the periods of inflation in 1970 and 1980 were quickly adjusted. However, more recently, there has been little evidence to suggest that changes in crude oil price influence inflation [3].

Falling oil prices also weakened the overall foreign earnings of the African oil-producing countries, resulting in rising inflation rates given the demand for foreign offshore products; specifically, demand did not fall for food items. Interestingly, African countries are classified as food-insecure countries [4]. In this instance, the price of goods and services continued to rise as oil prices fell, whereas during periods of high oil prices, the price of goods and services did not fall, indicating that oil price changes have a nonlinear effect on domestic prices. In 2016, the inflation rate in Angola, Libya, and Nigeria 
hit double digits. Notably, the inflation rate is usually volatile as there are various reasons for why it can change.

The oil boom during the mid-1970s was a case where the inflation rate was positively affected. Also, there is evidence to suggest that positive and negative changes in oil prices in the same proportion will impact inflation differently. For example, in 2008, when oil prices increased, the inflation showed a more substantial response compared to when the oil price decreased in 2006, while, during the middle of 2014, the oil price fell from US $\$ 115$ per barrel to $\$ 52$ per barrel and inflation rose. Interestingly, this did not follow the oil price hike pattern from the period between 2006 and 2008. The impact of oil price changes on inflation in oil-exporting countries is currently unclear, as increases in oil prices will increase the amount of revenue in the economy and create inflation. Interestingly, in those economies, oil price decreases still cause the inflation rate to increase. Therefore, this study aims to examine the impact of oil price changes on inflation in the African OPEC member countries Algeria, Angola, Libya, and Nigeria.

Figure 1 displays the global crude oil price from 1975 to 2015. The authors in [5] associate the period from 1973 to 1996 with assertive behavior by OPEC and, therefore, call this period "The age of OPEC" ([5] identifies five main periods associated with significant changes in the price of oil: 1859-1899, 1900-1945, 1946-1972, 1973-1996, and 1997-present). It can be seen that, between 1975 and 1979 , the price of crude oil stayed reasonably steady and only fluctuated by about US\$12-14 per barrel. Then, during the Iran-Iraq war and the Iranian Revolution, from 1979 to 1980, crude oil production was cut by $10 \%$, which, in turn, had the effect of increasing the price of crude oil from US\$14 to $\$ 35$ per barrel [6]. Indeed, increasing oil prices have led the leading firms and major players in the industry to broaden their search for oil and caused non-OPEC member countries to increase their oil production.

Although, from early 1982 to 1985, OPEC made an effort to stabilize the price of crude oil through production quotas, the slowdown of the global economy and the illegal quotas that OPEC member countries produced caused crude oil prices to drop to US $\$ 10$ per barrel. The striking features in Figure 1 are the 2008 and 2011-2013 oil price hikes. Oil prices increased gradually from 1998 to 2008 and reached the peak of US\$94 per barrel in 2008. In June 2014, the oil price level reached a maximum price of US $\$ 115$ per barrel, and, around January 2016, the price dropped to less than US $\$ 30$ per barrel due to the increasing oil supply from mostly non-OPEC countries. [7]. It is worth noting that OPEC's contribution to the world's oil supply had decreased from 55\% in 1976 to $42 \%$ in 2014, which shows that OPEC has slightly lost the means to control global oil prices.

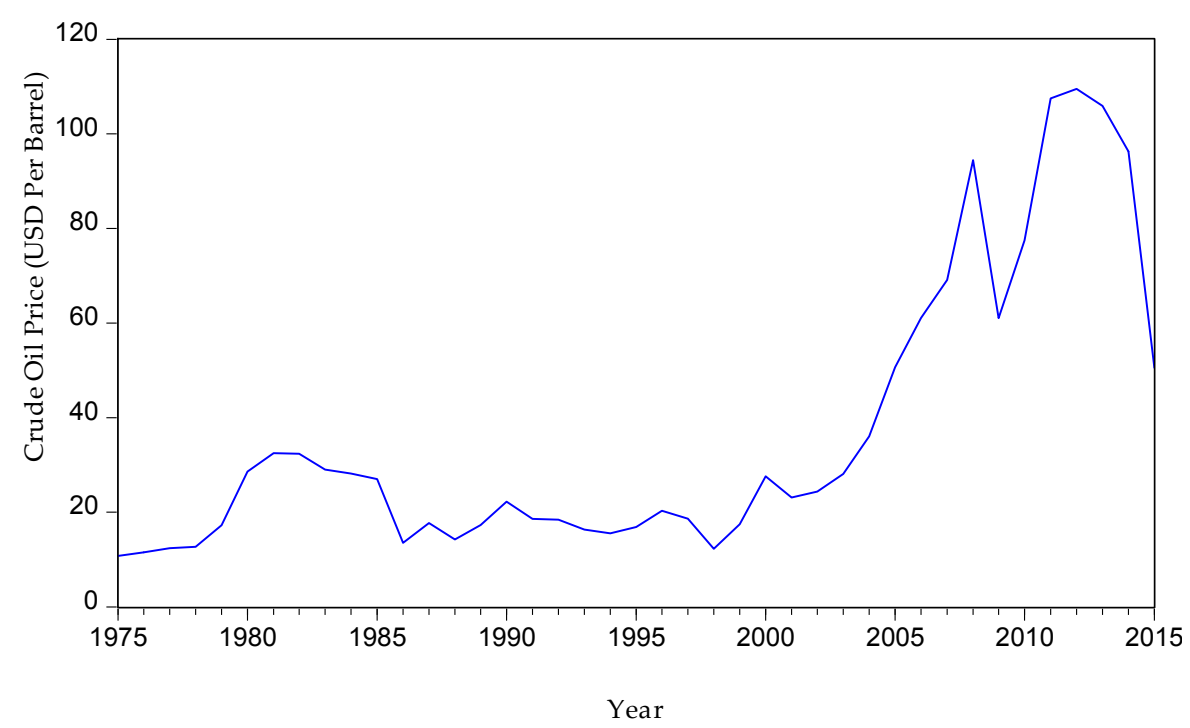

Figure 1. Crude oil price movements. Source: This graph was plotted by the first author based on the data reported in the OPEC Annual Statistical Report [8] using the software Econometric Views version 9 (Information Handling Services (IHS) Market Ltd., London, United Kingdom). 
Table 1 shows the exchange rates of, and money supply in, Algeria, Angola, Libya, and Nigeria. The central banks of these countries have frequently used monetary policies and exchange rate interventions to promote price stability and long-term economic growth. These four African oil producers experienced a depreciation in exchange rates in the period under study. In 1995, the official exchange rates of Algeria, Angola, Libya, and Nigeria were 47.66/USD, 0.001/USD, 0.42/USD, and 21.90/USD, respectively, whereas in 2014 they were 80.58/USD, 98.30/USD, 1.29/USD, and $158.55 /$ USD, respectively. Notably, all of these countries experienced a depreciation in their exchange rates. Table 1 displays the money supply in the African OPEC member countries from 1995 to 2014. In 1995, Libya had the highest money supply (79.62), followed by Angola (40.10), Algeria (37.16), and Nigeria (15.87). While the money supply in Algeria, Angola, and Nigeria increased gradually, the money supply in Libya increased threefold from 2010 to 2014. The leading causes of the money supply changes in Libya were the civil war and the political instability that affected crude oil production.

Table 1. African OPEC member countries' exchange rates and monetary policy.

\begin{tabular}{ccccccc}
\hline \multicolumn{1}{c}{ Years } & & $\mathbf{1 9 9 5}$ & $\mathbf{2 0 0 0}$ & $\mathbf{2 0 0 5}$ & $\mathbf{2 0 1 0}$ & $\mathbf{2 0 1 4}$ \\
\hline \multirow{3}{*}{ Exchange Rate } & Algeria & 47.66 & 75.26 & 73.28 & 74.39 & 80.58 \\
& Angola & 0.0027 & 10.04 & 87.16 & 91.91 & 98.30 \\
& Libya & 0.42 & 0.51 & 1.31 & 1.27 & 1.29 \\
& Nigeria & 21.90 & 101.70 & 131.27 & 150.30 & 158.55 \\
\hline \multirow{5}{*}{ Money Supply (M2) } & Algeria & 37.17 & 37.83 & 53.83 & 69.05 & 79.42 \\
& Angola & 40.10 & 17.28 & 15.90 & 35.33 & 41.00 \\
& Libya & 79.62 & 48.51 & 26.56 & 47.64 & 127.47 \\
& Nigeria & 15.87 & 21.96 & 17.73 & 21.03 & 20.16 \\
\hline
\end{tabular}

Data source: OPEC Annual Statistical Report [8]. Notes: The exchange rates were in local currency per USD and the money supply were measured in percentage of GDP.

Figure 2 shows the relationship between the oil price and the inflation rate in all oil-exporting countries in a nonlinear scatter plot. The graph reveals that, at the initial stage, the relationship was positive with a low oil price; however, when the oil price had increased to a certain point, the relationship became negative. Therefore, this shows that a nonlinear relationship is possible between the increase and decrease of oil prices that also has a different impact on inflation. As a robustness check, Figure A1 in the Appendix presents the nonlinear fit after dropping the United States from the scatter plot. The figure shows that such nonlinearity still exists.

This paper extends the existing literature in five directions. First and foremost, this research contributes towards assessing changes in the price of oil with regard to inflation in African OPEC member countries using each country's actual crude oil price. In contrast to the previous studies, which have used a global crude oil price, such as the Brent price, the West Texas Intermediate (WTI), or the Dubai Brent, this study uses each country's actual oil price, namely: Algeria (Zarzaitine), Angola (Cabinda), Libya (Brega), and Nigeria (Bonny Light). Indeed, this is important because each type of crude oil will have a different price.

Secondly, this study considers that the oil-exporting countries Algeria, Angola, Libya, and Nigeria are food-scarce countries, where more than half of the food is imported. Hence, the domestic food production has been included in the model. We believe that inflation in these countries is explained not only by the conventional sources of inflation but also by the availability of food. Our model is not only able to capture the effects of oil prices on the consumer price index (CPI) but is also able to capture the response of CPI to domestic food production.

Third, the monetary authorities or central banks of the African OPEC member countries have frequently intervened to manage the foreign exchange rate. This study provides monetary authorities and central banks with insight into which policy tools will be effective to stabilize economic activities; in particular, consumer prices that are brought about by external shocks in oil price changes. 
Fourth, in contrast to the majority of the previous literature, which has investigated oil prices in African OPEC member countries by employing the linear time-series model, this study provides recent empirical research that contributes to answering the question of whether there is a nonlinear impact from positive and negative oil price changes on inflation in African OPEC member countries.

Fifth, this study considers the potential international sources of inflation, such as the fluctuation of global gross domestic product (GDP), the United States' GDP, and China's GDP. It is of interest to find out whether the output shocks of these two economic giants have different impacts on inflation in the African OPEC member countries.

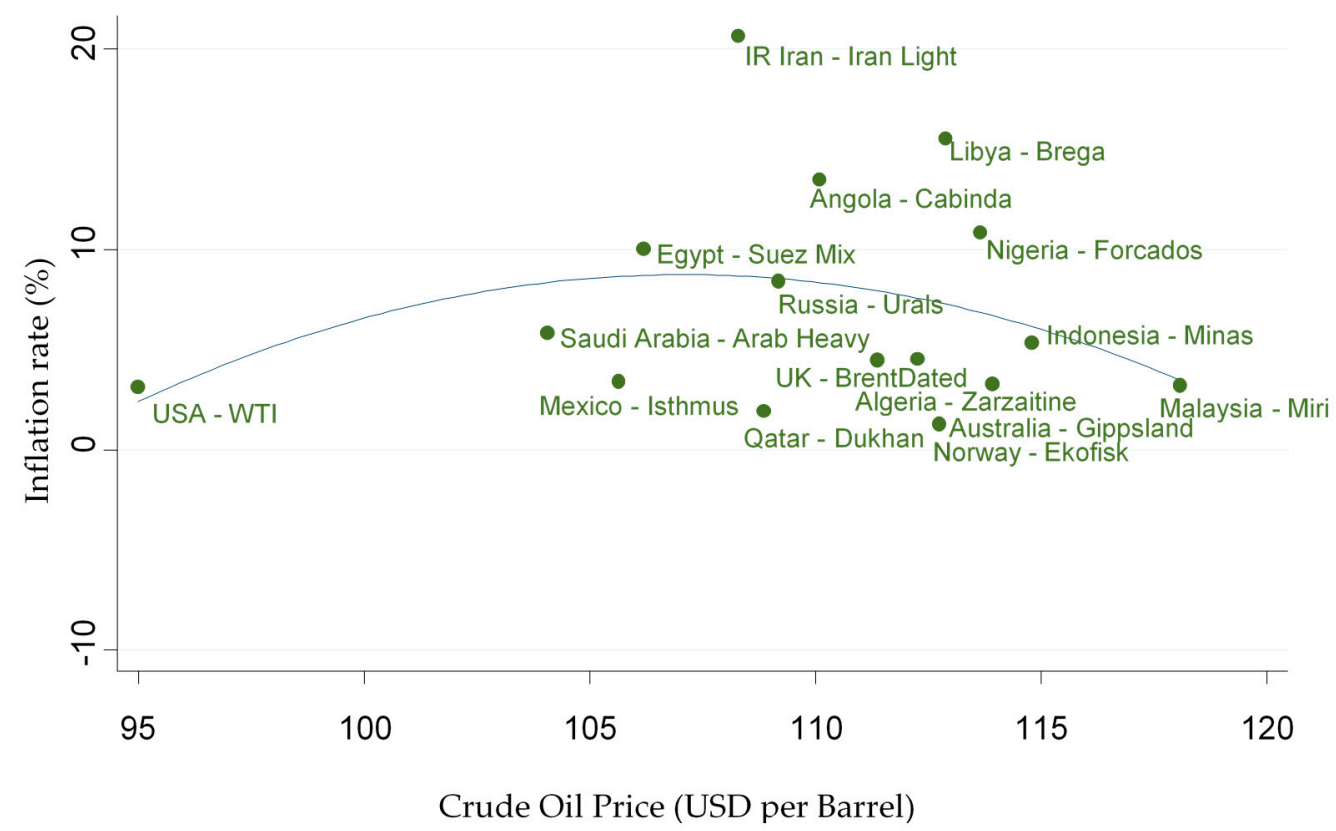

Figure 2. The crude oil price and inflation rates in oil-exporting countries. Notes: The curve was the best-fit curve to the scatter plot. The shaded area displays the $95 \%$ confidence intervals. The oil-exporting countries included in the graph and their respective oil prices are the United States (WTI), IR Iran (Iran Light), Libya (Brega), Angola (Cabinda), Egypt (Suez Mix), Nigeria (Forcados), Russia (Urais), Saudi (Arab Light), Dubai (Arab Heavy), Indonesia (Minas), Mexico (Isthmus), United Kingdom (Brent), Angola (Girassol), Malaysia (Miri), Australia (Gipp), Qatar (Dukhan), and Norway (Ekofisk). Source: This graph was plotted by the first author based on the data reported in the OPEC Annual Statistical Report [8] using the Stata Statistical Software Release 13 (StataCorp LP, TX, USA).

\section{Literature Review}

Most studies that have explored the impact of oil prices on inflation rates have employed the linear time-series model. By applying the Structural Vector autoregression (SVAR) method to examine the vulnerability of domestic prices to oil price shocks in ASEAN-4 countries, the authors in [9] found that a positive shock to the oil price could reduce the CPI in Indonesia but would increase the CPI in the Philippines and Thailand, while in Malaysia, there would be no significant effect on the CPI. The authors in [10] applied the Bayesian Vector autoregression (VAR) model to examine the impact of oil price and inflation in USA quarterly data from 1948Q1 to 2011Q2. They found that oil price fluctuations do not necessarily spread and result in changes to overall inflation but rather are time specific. Some of the subsequent researchers have attempted to investigate further the argument that oil price can affect CPI but not economic activities. The authors in [11] applied USA monthly data from January 1974 to July 2014, disaggregated the consumer price into five different components, and compared the impact of the oil price on each component separately. The results revealed that an oil price shock has significant positive effects on the energy-intensive CPI. The authors in [12] used the autoregressive distributed lag (ARDL) method to study the pass-through effect of oil prices 
on Malaysia's consumer prices. The results indicated that oil prices and inflation have a positive relationship. The authors in [13] estimated the dynamic effects of demand and supply shocks on the real price of oil and economic activity. The findings showed that the impact of higher oil prices on real GDP and CPI inflation in the United States depends on the cause of the oil price increase. There was evidence that the recent increase in crude oil prices was driven primarily by global aggregate demand shocks. On the contrary, the authors in [14] found that, since 1980, the oil price pass-through has become negligible. In a recent study [15], the authors found that a fluctuation in oil price is absorbed and disappears within the first five to six quarters after a shock occurs. Notably, shocks were found to not have any significant impact in the long run, especially when the oil price had been converted to domestic currency.

Some studies have applied nonlinear methods to examine the relationship between oil prices and inflation. The authors in [16] estimated monthly data from January 1981 to May 2011 and applied a nonlinear error-correction model. The results revealed that the oil price has long-term pass-through effects on the producer price in Taiwan. Moreover, the error-correction adjustment will be faster when the deviation of the price from the equilibrium is more substantial. Similar findings were reported in [17], where the authors investigated the asymmetric response of the gasoline price to changes in the oil price in France. In this study, they applied the ARDL method and found asymmetric relations with oil price changes, for which the gasoline prices gradually adjusted to a long-equilibrium position. In this case, the adjustment was found to be faster when the crude oil price increases rather than decreases. In a separate study, the authors in [18] found that Iran is greatly exposed to oil price changes that have asymmetric impacts on the economy. The study revealed that positive and negative oil price shocks significantly increase inflation, but the magnitude depends on the size of the shock. The authors in [19] showed that inflation is profoundly affected by oil price shocks and to some extent the impact is asymmetric. The authors confirmed this result by comparing the impact of a negative oil price shock to that of a positive shock that was noted in India. The authors in [20] applied a multivariate two-regime threshold VAR model to assess the impact of oil prices in Turkey and found that oil price changes have a significant effect on inflation when the changes exceed the optimal threshold point and have the ability to adversely influence macroeconomic variables.

The authors in [21] investigated the relationship between food price and oil price on Malaysian annual data from 1971 to 2012 and applied the nonlinear ARDL method to estimate the asymmetric impacts of the oil price on the food price. The study found an asymmetric relationship to exist between oil and food prices and that positive long-term oil prices significantly influence food prices, while negative oil prices do not affect food prices. The authors in [22] investigated the effects of global oil and food price shocks on consumer prices in MENA countries using cointegration threshold techniques. The short-run adjustment pattern in their case exhibited asymmetries and was particularly strong after positive shocks. The studies $[23,24]$ also found that global food inflation is an important source of inflationary pressures in the MENA region. Based on reduced-form VARs, the authors in [25] concluded that international commodity price inflation is the main determinant of producer and consumer food price inflation in the Euro area, with a pass-through coefficient of 0.3. According to the study [26], the impact of oil price inflation exceeds its counterpart from food price inflation for advanced economies. For emerging markets, the ordering is reversed, i.e., food price inflation becomes more important due to different second-round effects. The evidence is scarce for MENA countries. Following [23], a $1 \%$ increase in global food prices raises domestic food prices by $0.2-0.4 \%$. For some countries, such as Egypt and Morocco, the price transmission exhibits significant asymmetries, as price increases have stronger absolute effects on domestic inflation than price decreases.

In the study [27], the authors examined both internal and external factors influencing Ghana's inflation and found that in Ghana and the Ivory Coast, there is a significant intracontinental transfer of inflation. The study also found a negative correlation between the food production index (FPI) and inflation, which indicates that an increase in food supply reduces the inflation rate. Furthermore, after considering the uncertainty in oil price fluctuations, they suggested that to reduce the inflation rate 
the government should make a greater effort to secure foodstuffs. A recent study [28] examined the long-run impact of oil exports and food production on inflation in African OPEC member countries. The authors found that oil exports have a positive and significant impact that is connected to inflation, while increases in food production have a negative impact that is related to inflation. The literature also stresses that interactions between global factors and oil prices should be considered. The authors in [29] used a global-factor-augmented error-correction model to examine the relationship among oil prices, global industrial production, prices, the central bank policy interest rate, and the monetary aggregate. The authors found that the United States, the Euro area, and China are the main drivers of global macroeconomic factors.

The above discussion offers further insight into, and understanding of, how oil price shocks have been investigated in other studies. Many different methods have been applied in previous research studies to explore how various economic indicators are affected by oil price shocks. With respect to the impact of oil price shocks, there is still debate as to how symmetry and asymmetry bear upon the extent to which oil prices are endogenous. Also, all the above studies use a global crude oil price as a proxy for the oil price. In fact, as mentioned earlier, there are many types of crude oil price, as each country produces a different type of crude oil that also differs in price. Hence, this study intends to fill the gap in the literature by considering each African OPEC member country's actual crude oil price. Furthermore, this study also explores how domestic food production increases may reduce the rate of inflation and whether persistent increases in food prices result from shortages in food production.

\section{Theoretical Framework}

From the work of $[9,30,31]$, it can be concluded that the oil price has a direct effect on inflation in an economy, as it implies that an increase in oil price will lead to an increase in the general price level. Crude oil is one of the most fundamental and crucial raw materials in industrial production. Oil price shocks can increase the marginal cost of production in many industries and thus reduce the production. This is referred to as the supply-side shock effect. Upstream cost shocks in an industry can be transmitted from producers and sectors to end-users. A well-developed industrial chain can transmit an inflationary shock from upstream to downstream, which will slightly affect the producers' profit rate [31]. This is called the inflation effect. Oil price shocks can raise the overall cost for consumers and producers, thus reducing the consumption rate and the real output as well. When the output decreases, monetary authorities may respond by promulgating an expansionary monetary policy to stimulate economic growth, which may push up the prices. In this section, we will test the validity of the transmission mechanisms of oil price shocks to the consumer's price by checking the statistical relationships between the key variables in the transmission chain shown in Figure 3.

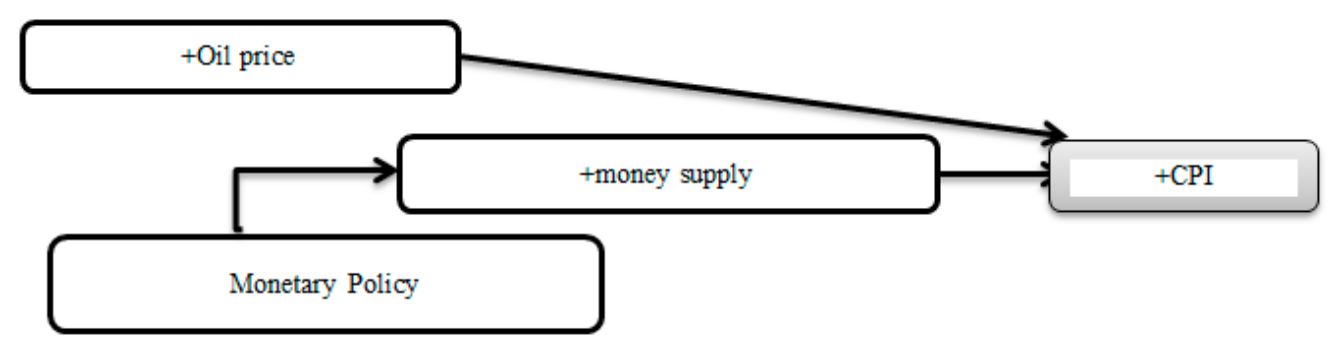

Figure 3. The oil price transmission channel into the consumer price index (CPI). 


\section{Methodology, Data, and Sources}

\subsection{Specification of the Panel of ARDL Models}

The extracted theoretical framework for the oil price and the inflation channel can be written as

$$
c p i=f(o p, m)
$$

where cpi is the consumer price index as a proxy for inflation, op is the spot oil price, and $m$ is the money supply. In addition, this study included FPI in the oil price and inflation model because the four African OPEC member countries under consideration (Algeria, Angola, Libya, and Nigeria) are food-scarce countries. As noted by [32], domestic food prices are affected by global crude oil price shocks, especially in countries with high levels of subsistence food production. The authors in $[27,28]$ had included a food production index in their model to examine the role of domestic food production in the consumer price level. The studies found that there is a negative relationship between the food production index and inflation, indicating that an increase in food supply reduces the inflation rate. Therefore, Equation (1) can be extended as follows:

$$
c p i=f(o p, m, f p i) \text {. }
$$

Next, the impact of oil price changes on inflation in the four African OPEC member countries is examined with the dynamic approach using a linear formulation and a nonlinear formulation. We rewrite Equation (2) in the econometrics linear ARDL format in Equation (3). In Equation (4), the nonlinear specification model is used to detect whether an asymmetric relationship exists between the oil price and inflation in accordance with the nonlinear autoregressive distributed lag (NARDL) panel setup in Equation (4).

$$
\begin{gathered}
l c p i_{i t}=\alpha_{0}+\beta_{1} \operatorname{lop}_{i t}+\beta_{2} l m_{i t}+\beta_{3} l f p i_{i t}+\beta_{4} l X_{i t}+\mu_{i t} \\
l c p i_{i t}=\alpha_{0}+\beta_{1} l o p_{i t}^{+}+\beta_{2} l o p_{i t}^{-}+\beta_{3} l m_{i t}+\beta_{4} l f p i_{i t}+\beta_{5} l X_{i t}+\mu_{i t}
\end{gathered}
$$

where $l c p i_{t}$ is the log of the consumer price index, $l o p_{t}^{+}$and $l o p_{t}^{-}$are positive and negative oil price changes, respectively, $l m_{t}$ is a log of the money supply as monetary policy instruments, $l f p i_{t}$ is the log of the food production index, and $l X_{i t}$ denotes the other control variables (exchange rate and GDP). The inclusion of these control variables was motivated by the role of monetary policy in sharpening the economy during oil price shocks. If the monetary authorities act to hold the growth of the nominal GDP constant, the inflation rate will accelerate at the same rate at which the real GDP growth slows. If the monetary authorities hold the nominal exchange rate constant, the inflation rate will decrease and the pressure on foreign currencies will increase (see [33]). The symbols $\left(\beta_{1,}, \beta_{2}, \beta_{3}, \beta_{4}\right)$ represent the coefficient vectors of the long-term parameters to be estimated.

From the linear model (Equation (3)), it is expected that $\beta_{1}$, and $\beta_{2}$, will be positive while $\beta_{3}$ will be negative on inflation. The model represents all four African OPEC members (Algeria, Angola, Libya, and Nigeria). Based on the nonlinear model (Equation (4)), the formation of the long-run impacts of oil price increases on inflation is $\beta_{1}$ in Equation (5), which is expected to be positive. Meanwhile, $\beta_{2}$ in Equation (6) captures the long-term relations between the reductions in oil price on inflation. It is expected to move in the same direction, so $\beta_{2}$ is expected to be positive. In addition, the reduction in oil price has a greater impact on rising inflation compared to increases in oil price with the same magnitude, i.e., $\beta_{2}>\beta_{1}$.

$$
\begin{aligned}
& \beta_{1} o p_{i t}^{+}=\sum_{j=1}^{t} \Delta o p_{j}^{+}=\sum_{j=1}^{t} \max \left(\Delta o p_{j}, 0\right) \\
& \beta_{2} o p_{i t}^{-}=\sum_{j=1}^{t} \Delta o p_{j}^{-}=\sum_{j=1}^{t} \min \left(\Delta o p_{j}, 0\right)
\end{aligned}
$$


The authors in [34] framed a NARDL setting along with the extension techniques [35,36], which are expressed in ARDL as

$$
\begin{aligned}
\Delta l c p i_{i t}= & \alpha_{0}+\beta_{1} l c p i_{i t-1}+\beta_{2} l o p_{i t}^{+}+\beta_{3} l o p_{i t}^{-}+\beta_{4} l m_{i t}+\beta_{5} l f p i_{i t}+\beta_{5} l X_{i t} \\
& +\sum_{i=1}^{p} \pi_{i} \Delta l c p i_{i t-i}+\sum_{i=1}^{p} O_{i} \Delta l c p i_{i t-i}+\sum_{i=0}^{q} p_{i} \Delta l m_{i t-i}+\sum_{i=0}^{q} p_{i} \Delta l f p i_{i t-i} \\
& +\sum_{i=0}^{q} p_{i} \Delta l X_{i t-i}+\sum_{i=0}^{q}\left(\alpha_{i}^{+} \Delta l o p_{i t-i}^{+}+\alpha_{i}^{-} \Delta l o p_{i t-i}^{-}\right)+\mu_{i t}
\end{aligned}
$$

where $p$ and $q$ are lag orders, and $\beta_{2}=-\beta_{2} / \alpha_{0}$ and $\beta_{3}=-\beta_{3} / \alpha_{0}$ are the aforementioned long-term impacts of an oil price increase and an oil price reduction, respectively, on inflation. $\sum_{i=0}^{q} \alpha_{i}^{+}$is the measure of the short-term influences of an oil price increase on inflation, while $\sum_{i=0}^{q} \alpha_{i}^{-}$is the short-term influences of an oil price reduction on inflation. Hence, in this setting, in addition to the asymmetric long-term relation, the asymmetric short-term influences of oil price changes on inflation are also captured. The procedures that were used in the analysis are as follows. First, preliminary tests were used to examine the nature of the data for each variable and its structure.

Four different panel unit-root tests were used to examine the data, namely Levin, Lin, and Chu [37], Im, Pesaran and Shin [38], and Fisher-ADF and Fisher PP [39]. Second, this study employed the Pedroni residual test, which is based on the panel cointegration procedure. The pooled mean group (PMG) and mean group (MG) estimators have been used to detect the short-term and long-term coefficients, including the error-correction term. Furthermore, this study examined the impacts of oil price changes with a nonlinear formulation using the same PMG and MG estimators. Three different proxies of oil price were used: the specific country's oil price, the OPEC reference oil price, and an average of the Brent, WTI, and Dubai oil price.

We also performed a robustness check on the baseline formulation by adding the potential international sources of inflation (see for example $[13,29,40]$ ). It is important to know whether the results hold after controlling for international sources of inflation. We provide three sets of robustness checks, which involve global GDP, the United States' GDP, and China's GDP. This is because, according to [41], China is the world's largest oil consumer, followed by the United States. These two countries together use about one-third of the oil the world produces. Besides this, the United States and China are also the major trading partners of the African OPEC member countries. According to the trade data provided by [42], World Bank, the United States was the top origin of imports for Nigeria from 1996 to 2006 and it became second from 2007 to 2014. China was ranked ninth in 1996, but it overtook the United States to become the top origin of imports for Nigeria from 2007 to 2014. The United States ranked 3rd and 6th as the origin of imports for Algeria in 1996 and 2014, while China ranked 10th as the origin of imports for Algeria in 1996 and became 1st in 2013-2014. The United States ranked third as the origin of imports for Angola from 2007 to 2014. China ranked fifth as the origin of imports for Angola in 2007 and became second from 2009 to 2014. China ranked second as the origin of imports for Libya from 2007 to 2010, while the United States ranked sixth and seventh as the origin of imports for Libya in 2007 and 2010, respectively. In addition, empirical studies have found that the United States and China are the main drivers of global macroeconomic factors (see for example [29,43]).

\subsection{Data and Sources}

This study applied a strongly balanced panel of data comprising the oil price, the CPI, the money supply (M2), the food production index (FPI), the exchange rate (E), and the gross domestic product (GDP). This study used annual data from the period 1995-2014. The data were chosen based on their availability. The sample countries Algeria, Angola, Libya, and Nigeria were selected given that they are all members of OPEC and share the same continent. The oil price data used were the OPEC reference oil price, an average of the Brent, WTI, and Dubai oil price, and each country's individual oil price, namely, the Saharan Blend oil price for Algeria, the Girassol oil price for Angola, the Ess Sider oil price for Libya, and the Bonny Light oil price for Nigeria. The average CPI was used as a proxy for 
inflation, and M2 in USD was used as a proxy for the money supply. The FPI was used as a proxy for food production, the average official exchange rate against USD was used as a proxy for the exchange rate, and GDP in constant USD was used as a proxy for economic growth. The data were converted to their natural log values. The descriptive statistics of the variables are presented as Table A1 in the Appendix A.

\section{Results and Discussion}

\subsection{Panel Unit-Root Test}

It is recommended that, before conducting a panel cointegration test, the level of stationarity of the variables is identified. As stated earlier, four different approaches to the unit-root test were applied to confirm the stationarity of each variable. The Fisher-ADF and Fisher PP unit-root tests are reasonably straightforward and nonparametric unit-root tests. The tests were conducted in two different modes; initially, the tests were carried out with an intercept and with an intercept and a linear trend for all methods.

Table 2 presents the results from the panel unit-root data tests. The results reveal that the null hypothesis cannot be rejected at the level form for the CPI, FPI, and GDP variables. The other variables-OPC, OPEC, OP, E, and M2-are stationary at the level form. OPC, OPEC, and OP are stationary when the trend is used in Levin-Lin-Chu (LLC) and Im-Pesaran-Shin (IPS) tests, while, without the trend, they are rejected. E is stationary only when not using the trend in LLC, while M2 is stationary only when the trend is used in LLC. Moreover, all of the variables are stationary after being converted into the first difference. In summary, the stationarity results from the four different techniques confirm the fact that all the variables are free from the unit-root in the second difference. The next step is to conduct the panel cointegration test.

Table 2. Panel unit-root results.

\begin{tabular}{|c|c|c|c|c|c|c|c|c|c|}
\hline \multirow[t]{2}{*}{ Variable } & \multirow{2}{*}{ Assumption } & LLC & IPS & $\begin{array}{l}\text { Fisher- } \\
\text { ADF }\end{array}$ & $\begin{array}{l}\text { Fisher } \\
\text { PP }\end{array}$ & LLC & IPS & $\begin{array}{l}\text { Fisher- } \\
\text { ADF }\end{array}$ & $\begin{array}{l}\text { Fisher } \\
\text { PP }\end{array}$ \\
\hline & & \multicolumn{4}{|c|}{ Level } & \multicolumn{4}{|c|}{ First Difference } \\
\hline \multirow{2}{*}{ CPI } & No trend & $\begin{array}{c}7.11 \\
(1.00)\end{array}$ & $\begin{array}{l}7.17 \\
(1.00)\end{array}$ & $\begin{array}{c}0.50 \\
(0.99)\end{array}$ & $\begin{array}{c}0.16 \\
(1.00)\end{array}$ & $\begin{array}{c}-2.41^{* * *} \\
(0.00)\end{array}$ & $\begin{array}{c}-1.82 * * \\
(0.03)\end{array}$ & $\begin{array}{c}16.70^{* * * *} \\
(0.03)\end{array}$ & $\begin{array}{l}14.61 \\
(0.06)\end{array}$ \\
\hline & Trend & $\begin{array}{l}-0.29 \\
(0.38)\end{array}$ & $\begin{array}{l}1.84 \\
(0.96)\end{array}$ & $\begin{array}{c}4.99 \\
(0.75)\end{array}$ & $\begin{array}{c}3.17 \\
(0.92)\end{array}$ & $\begin{array}{c}-2.03^{* *} \\
(0.02)\end{array}$ & $\begin{array}{c}-1.87^{* *} \\
(0.03)\end{array}$ & $\begin{array}{c}15.74^{* *} \\
(0.04)\end{array}$ & $\begin{array}{c}32.48^{* * *} \\
(0.00)\end{array}$ \\
\hline \multirow{2}{*}{ OPC } & No trend & $\begin{array}{l}-0.86 \\
(0.19)\end{array}$ & $\begin{array}{c}1.73 \\
(0.95)\end{array}$ & $\begin{array}{c}1.58 \\
(0.99)\end{array}$ & $\begin{array}{c}1.08 \\
(0.99)\end{array}$ & $\begin{array}{c}-5.48^{* * *} \\
(0.00)\end{array}$ & $\begin{array}{c}-5.28^{* * *} \\
(0.00)\end{array}$ & $\begin{array}{c}40.41^{* * * *} \\
(0.00)\end{array}$ & $\begin{array}{c}73.05^{* * *} \\
(0.00)\end{array}$ \\
\hline & Trend & $\begin{array}{c}-4.00 * * * \\
(0.00)\end{array}$ & $\begin{array}{c}-1.66^{* *} \\
(0.04)\end{array}$ & $\begin{array}{l}13.58 \\
(0.09)\end{array}$ & $\begin{array}{l}11.53 \\
(0.17)\end{array}$ & $\begin{array}{c}-4.04 * * * \\
(0.00)\end{array}$ & $\begin{array}{c}-3.79 * * * \\
(0.00)\end{array}$ & $\begin{array}{c}27.91 * * * \\
(0.00)\end{array}$ & $\begin{array}{c}70.78^{* * *} \\
(0.00)\end{array}$ \\
\hline \multirow{2}{*}{ OPEC } & No trend & $\begin{array}{l}-0.78 \\
(0.21)\end{array}$ & $\begin{array}{c}1.80 \\
(0.96)\end{array}$ & $\begin{array}{c}1.49 \\
(0.99)\end{array}$ & $\begin{array}{c}1.02 \\
(0.99)\end{array}$ & $\begin{array}{c}-5.35 * * * \\
(0.00)\end{array}$ & $\begin{array}{c}-5.25^{* * *} \\
(0.00)\end{array}$ & $\begin{array}{c}40.17^{* * * *} \\
(0.00)\end{array}$ & $\begin{array}{c}63.32 * * * \\
(0.00)\end{array}$ \\
\hline & Trend & $\begin{array}{c}-3.98^{* * *} \\
(0.00)\end{array}$ & $\begin{array}{l}-1.63 \\
(0.05)\end{array}$ & $\begin{array}{l}13.43 \\
(0.09)\end{array}$ & $\begin{array}{l}11.49 \\
(0.17)\end{array}$ & $\begin{array}{c}-4.10^{* * *} \\
(0.00)\end{array}$ & $\begin{array}{c}-3.79 * * * \\
(0.00)\end{array}$ & $\begin{array}{c}27.92^{* * * *} \\
(0.00)\end{array}$ & $\begin{array}{c}73.68^{* * *} \\
(0.00)\end{array}$ \\
\hline \multirow{2}{*}{ OP } & No trend & $\begin{array}{l}-0.86 \\
(0.19)\end{array}$ & $\begin{array}{c}1.76 \\
(0.96)\end{array}$ & $\begin{array}{c}1.55 \\
(0.99)\end{array}$ & $\begin{array}{c}1.02 \\
(0.99)\end{array}$ & $\begin{array}{c}-5.72 * * * \\
(0.00)\end{array}$ & $\begin{array}{c}-5.07^{* * *} \\
(0.00)\end{array}$ & $\begin{array}{c}38.77^{* * * *} \\
(0.00)\end{array}$ & $\begin{array}{c}73.68^{* * *} \\
(0.00)\end{array}$ \\
\hline & Trend & $\begin{array}{c}-0.42^{* * *} \\
(0.00)\end{array}$ & $\begin{array}{c}-1.89 * * \\
(0.02)\end{array}$ & $\begin{array}{l}14.84 \\
(0.06)\end{array}$ & $\begin{array}{l}13.19 \\
(0.10)\end{array}$ & $\begin{array}{c}-7.93 \text { *** } \\
(0.00)\end{array}$ & $\begin{array}{c}-6.32^{* * *} \\
(0.00)\end{array}$ & $\begin{array}{c}43.26^{* * *} \\
(0.00)\end{array}$ & $\begin{array}{c}66.82 * * * \\
(0.00)\end{array}$ \\
\hline \multirow{2}{*}{ M2 } & No trend & $\begin{array}{l}-0.38 \\
(0.35)\end{array}$ & $\begin{array}{l}-0.52 \\
(0.29)\end{array}$ & $\begin{array}{c}9.21 \\
(0.32)\end{array}$ & $\begin{array}{c}6.40 \\
(0.60)\end{array}$ & $\begin{array}{c}-5.90 * * * \\
(0.00)\end{array}$ & $\begin{array}{c}-4.20^{* * *} \\
(0.00)\end{array}$ & $\begin{array}{c}32.76^{* * *} \\
(0.00)\end{array}$ & $\begin{array}{c}56.21^{* * *} \\
(0.00)\end{array}$ \\
\hline & Trend & $\begin{array}{c}-1.90 * * \\
(0.02)\end{array}$ & $\begin{array}{l}-0.08 \\
(0.46)\end{array}$ & $\begin{array}{c}8.62 \\
(0.37)\end{array}$ & $\begin{array}{c}8.79 \\
(0.36)\end{array}$ & $\begin{array}{c}-6.11^{* * *} \\
(0.00)\end{array}$ & $\begin{array}{c}-5.29 * * * \\
(0.00)\end{array}$ & $\begin{array}{c}36.79 * * * \\
(0.00)\end{array}$ & $\begin{array}{c}48.22 * * * \\
(0.00)\end{array}$ \\
\hline
\end{tabular}


Table 2. Cont.

\begin{tabular}{|c|c|c|c|c|c|c|c|c|c|}
\hline \multirow{2}{*}{ Variable } & \multirow[t]{2}{*}{ Assumption } & LLC & IPS & $\begin{array}{l}\text { Fisher- } \\
\text { ADF }\end{array}$ & $\begin{array}{c}\text { Fisher } \\
\text { PP }\end{array}$ & LLC & IPS & $\begin{array}{l}\text { Fisher- } \\
\text { ADF }\end{array}$ & $\begin{array}{l}\text { Fisher } \\
\text { PP }\end{array}$ \\
\hline & & \multicolumn{4}{|c|}{ Level } & \multicolumn{4}{|c|}{ First Difference } \\
\hline \multirow{2}{*}{ FPI } & No trend & $\begin{array}{c}2.84 \\
(0.99)\end{array}$ & $\begin{array}{c}3.23 \\
(0.99)\end{array}$ & $\begin{array}{c}2.30 \\
(0.97)\end{array}$ & $\begin{array}{c}2.49 \\
(0.96)\end{array}$ & $\begin{array}{c}0.20 \\
(0.58)\end{array}$ & $\begin{array}{c}-4.25^{* * *} \\
(0.00)\end{array}$ & $\begin{array}{c}33.71 * * * \\
(0.00)\end{array}$ & $\begin{array}{c}75.84^{* * *} \\
(0.00)\end{array}$ \\
\hline & Trend & $\begin{array}{c}0.25 \\
(0.60)\end{array}$ & $\begin{array}{l}-0.61 \\
(0.27)\end{array}$ & $\begin{array}{l}10.76 \\
(0.21)\end{array}$ & $\begin{array}{l}13.64 \\
(0.09)\end{array}$ & $\begin{array}{c}1.05 \\
(0.85)\end{array}$ & $\begin{array}{c}-5.88^{* * *} \\
(0.00)\end{array}$ & $\begin{array}{c}41.43^{* * *} \\
(0.00)\end{array}$ & $\begin{array}{c}63.05^{* * *} \\
(0.00)\end{array}$ \\
\hline \multirow{2}{*}{ E } & No trend & $\begin{array}{c}-1.74^{* *} \\
(0.04) \\
\end{array}$ & $\begin{array}{l}-0.29 \\
(0.38) \\
\end{array}$ & $\begin{array}{c}6.80 \\
(0.55) \\
\end{array}$ & $\begin{array}{c}7.81 \\
(0.45) \\
\end{array}$ & $\begin{array}{c}-5.28^{* * *} \\
(0.00)\end{array}$ & $\begin{array}{c}-4.17^{* * *} \\
(0.00)\end{array}$ & $\begin{array}{c}31.11 * * * \\
(0.00)\end{array}$ & $\begin{array}{c}28.61 \text { *** } \\
(0.00)\end{array}$ \\
\hline & Trend & $\begin{array}{l}-0.89 \\
(0.19)\end{array}$ & $\begin{array}{l}-0.31 \\
(0.37)\end{array}$ & $\begin{array}{c}9.15 \\
(0.32)\end{array}$ & $\begin{array}{c}2.98 \\
(0.93)\end{array}$ & $\begin{array}{c}-4.81^{* * *} \\
(0.00)\end{array}$ & $\begin{array}{c}-3.21 * * * \\
(0.00)\end{array}$ & $\begin{array}{c}23.05^{* * *} \\
(0.00)\end{array}$ & $\begin{array}{c}21.74 * * \\
(0.02\end{array}$ \\
\hline \multirow{2}{*}{ GDP } & No trend & $\begin{array}{c}3.16 \\
(0.99)\end{array}$ & $\begin{array}{c}4.32 \\
(1.00)\end{array}$ & $\begin{array}{c}3.45 \\
(0.90)\end{array}$ & $\begin{array}{c}3.33 \\
(0.91)\end{array}$ & $\begin{array}{c}-6.94^{* * *} \\
(0.00)\end{array}$ & $\begin{array}{c}-6.07^{* * *} \\
(0.00)\end{array}$ & $\begin{array}{c}45.56^{* * *} \\
(0.00)\end{array}$ & $\begin{array}{c}49.80^{* * *} \\
(0.00)\end{array}$ \\
\hline & Trend & $\begin{array}{l}-1.41 \\
(0.07)\end{array}$ & $\begin{array}{c}0.51 \\
(0.69)\end{array}$ & $\begin{array}{c}5.78 \\
(0.67)\end{array}$ & $\begin{array}{c}5.93 \\
(0.65)\end{array}$ & $\begin{array}{c}-7.67 * * * \\
(0.00)\end{array}$ & $\begin{array}{c}-6.46^{* * *} \\
(0.00)\end{array}$ & $\begin{array}{c}45.52 * * * \\
(0.00)\end{array}$ & $\begin{array}{c}63.41 * * * \\
(0.00)\end{array}$ \\
\hline
\end{tabular}

Notes: The figures in parentheses are probability values. ${ }^{*}, * *$ and ${ }^{* * *}$ denote a rejection of the null hypothesis of nonstationary at the $10 \%, 5 \%$ and $1 \%$ levels of significance, respectively. The maximum numbers of lag lengths were selected based on the Akaike information criterion (AIC).

\subsection{Panel Cointegration Results}

The unit-root test results indicated that the variables are stationary. From there, the study moved on to determining whether there are long-term relations among the variables in the models. The panel cointegration test that was proposed in [44] was used. The panel cointegration test, which has heterogeneous features, also allows for cross-sectional interdependence with different individual effects. Pedroni provides seven different sets of residual-based tests, which are divided into two groups. Four out of the seven tests are within-dimension tests (the panel v-statistic test, the panel rho-statistic test, the panel PP-statistic test, and the panel ADP-statistic test). The remaining three tests are between-dimension tests (the group rho-statistic test, the group PP-statistic test, and the group ADF-statistic test).

Within-dimension regression is based on pooling the estimators in the autoregressive coefficient across individual countries on the residuals, while between-dimension regression is based on averaging the individual coefficient estimators of each country. The panel cointegration tests between the oil price and inflation were conducted under two different formulations, namely, linear and nonlinear. The results of the panel cointegration test based on the linear formulation are presented in Table A2 of the Appendix A. The cointegration results reveal that three to four out of the seven null hypotheses of no cointegration have been rejected at the $1 \%$ and the $5 \%$ levels of significance. Therefore, the models are cointegrated both within the dimension and between dimensions.

For the nonlinear formulation, this study employed the robust model from the linear formulation and partitioned the oil price into positive and negative changes. Additionally, this study partitioned the three different oil price proxies-the country-specific oil price (OPC), the OPEC reference basket oil price (OPEC), and the average of the U.K. Brent, the USA WTI, and the Dubai oil price (OP)—into positive and negative changes. Table 3 presents the results of the panel cointegration test based on the nonlinear formulation. For each model, the first columns are estimated without the trend while the second columns include the trend. The cointegration results in Table 3 reveal that four out of the seven null hypotheses in the three models have been rejected at the $1 \%$ and $5 \%$ levels of significance. Therefore, there is evidence of a long-term nonlinear relationship between the oil price and inflation in the African OPEC member countries, both within the dimension and between dimensions. 
Table 3. Nonlinear panel cointegration test results.

\begin{tabular}{|c|c|c|c|c|c|c|}
\hline \multirow{3}{*}{$\begin{array}{l}\text { Model } \\
\text { Equation } \\
\text { Assumption }\end{array}$} & \multicolumn{2}{|c|}{ Model 1} & \multicolumn{2}{|c|}{ Model 2} & \multicolumn{2}{|c|}{ Model 3} \\
\hline & \multicolumn{2}{|c|}{$\begin{array}{c}C P I=f\left(O P^{+}, O P^{-},\right. \\
M 2, E, F P, G D P)\end{array}$} & \multicolumn{2}{|c|}{$\begin{array}{c}C P I=f\left(O P E C^{+}, O P E C^{-}\right. \\
M 2, E, F P, G D P)\end{array}$} & \multicolumn{2}{|c|}{$\begin{array}{c}C P I=f\left(O P C^{+}, O P C^{-}\right. \\
M 2, E, F P, G D P)\end{array}$} \\
\hline & $\begin{array}{l}\text { Model w/o } \\
\text { trend }\end{array}$ & $\begin{array}{l}\text { Model with } \\
\text { trend }\end{array}$ & $\begin{array}{l}\text { Model w/o } \\
\text { trend }\end{array}$ & $\begin{array}{l}\text { Model with } \\
\text { trend }\end{array}$ & $\begin{array}{l}\text { Model w/o } \\
\text { trend }\end{array}$ & $\begin{array}{l}\text { Model with } \\
\text { trend }\end{array}$ \\
\hline $\begin{array}{l}\text { Panel } \\
\text { v-statistic }\end{array}$ & $\begin{array}{c}-0.1030 \\
(0.54)\end{array}$ & $\begin{array}{c}-0.3197 \\
(0.62)\end{array}$ & $\begin{array}{c}-0.1388 \\
(0.55)\end{array}$ & $\begin{array}{c}-0.4456 \\
(0.67) \\
\end{array}$ & $\begin{array}{c}-0.1593 \\
(0.56)\end{array}$ & $\begin{array}{c}-0.4650 \\
(0.67)\end{array}$ \\
\hline $\begin{array}{l}\text { Panel } \\
\text { rho-statistic }\end{array}$ & $\begin{array}{l}1.0994 \\
(0.86)\end{array}$ & $\begin{array}{l}1.7611 \\
(0.96)\end{array}$ & $\begin{array}{l}1.1786 \\
(0.88)\end{array}$ & $\begin{array}{l}1.8051 \\
(0.96)\end{array}$ & $\begin{array}{l}1.1760 \\
(0.88)\end{array}$ & $\begin{array}{l}1.8150 \\
(0.96)\end{array}$ \\
\hline $\begin{array}{l}\text { Panel } \\
\text { PP-statistic }\end{array}$ & $\begin{array}{c}-5.4535^{* * *} \\
(0.00)\end{array}$ & $\begin{array}{c}-5.1350^{* * *} \\
(0.00)\end{array}$ & $\begin{array}{c}-5.6242^{* * *} \\
(0.00)\end{array}$ & $\begin{array}{c}-5.2748^{* * *} \\
(0.00)\end{array}$ & $\begin{array}{c}-5.4877^{* * *} \\
(0.00)\end{array}$ & $\begin{array}{c}-5.1856^{* * *} \\
(0.00)\end{array}$ \\
\hline $\begin{array}{l}\text { Panel } \\
\text { ADF-statistic }\end{array}$ & $\begin{array}{c}-7.5297^{* * *} \\
(0.00)\end{array}$ & $\begin{array}{c}-6.7085^{* * *} \\
(0.00)\end{array}$ & $\begin{array}{c}-8.3785^{* * *} \\
(0.00)\end{array}$ & $\begin{array}{c}-7.2733^{* * *} \\
(0.00)\end{array}$ & $\begin{array}{c}-8.2525^{* * *} \\
(0.00)\end{array}$ & $\begin{array}{c}-7.2418^{* * *} \\
(0.00)\end{array}$ \\
\hline $\begin{array}{l}\text { Group } \\
\text { rho-statistic }\end{array}$ & $\begin{array}{c}2.2824 \\
(0.98) \\
\end{array}$ & $\begin{array}{l}2.5763 \\
(0.99)\end{array}$ & $\begin{array}{l}2.3969 \\
(0.99)\end{array}$ & $\begin{array}{l}2.7397 \\
(0.99)\end{array}$ & $\begin{array}{l}2.3887 \\
(0.99)\end{array}$ & $\begin{array}{l}2.7185 \\
(0.99)\end{array}$ \\
\hline $\begin{array}{l}\text { Group } \\
\text { PP-statistic }\end{array}$ & $\begin{array}{c}-2.0298^{* *} \\
(0.02)\end{array}$ & $\begin{array}{c}-1.8908^{* *} \\
(0.02)\end{array}$ & $\begin{array}{c}-1.9966^{* *} \\
(0.02)\end{array}$ & $\begin{array}{c}-1.8098^{* *} \\
(0.03)\end{array}$ & $\begin{array}{c}-1.9178^{* *} \\
(0.02)\end{array}$ & $\begin{array}{c}-1.8415 \text { ** } \\
(0.03)\end{array}$ \\
\hline $\begin{array}{l}\text { Group } \\
\text { ADF-statistic }\end{array}$ & $\begin{array}{c}-3.8141^{* * *} \\
(0.00)\end{array}$ & $\begin{array}{c}-2.9324 * * * \\
(0.00)\end{array}$ & $\begin{array}{c}-4.4643^{* * *} \\
(0.00)\end{array}$ & $\begin{array}{c}-3.1794^{* * *} \\
(0.00)\end{array}$ & $\begin{array}{c}-4.4129 * * * \\
(0.00)\end{array}$ & $\begin{array}{c}-3.2274^{* * *} \\
(0.00)\end{array}$ \\
\hline
\end{tabular}

Notes: the figures in parentheses are the probability values. ${ }^{*}, * *$, and ${ }^{* * *}$ denote the $10 \%, 5 \%$, and $1 \%$ levels of significance, respectively. Number of countries $(N)=4$ and periods $(T)=20$. The maximum numbers of lags were automatically selected by the Akaike information criterion (AIC).

\section{3. $P M G$ and MG Results}

Since we found evidence of a long-term relationship from the various oil price change and inflation models, we used the PMG and MG estimators to estimate short-term and long-term dynamic relationships with the presence of an error-correction term. After the two methodologies were applied, the Hausman test was used to identify the most suitable estimator for the model. The results from the linear PMG and MG estimators are presented in Table A3 of the Appendix A. The Hausman test indicates that PMG is the appropriate model. The PMG results were found to be in accordance with the assumptions that were adopted in the study.

Table 4 provides the results from the nonlinear formulation for the PMG and MG models with the three different proxies of oil prices (OP, OPEC, and OPC). The impacts of oil prices on inflation are separated into two parts (positive and negative changes). Next, we applied the Hausman test to identify the most suitable estimator for the model between the PMG and MG estimators, and PMG was found to be the appropriate model. The results from the PMG model reveal that both positive and negative oil price changes positively influence inflation in an asymmetric way. The results from the three models of oil prices (OPC, OPEC, and OP) reveal that a $1 \%$ increase in oil price is related to $0.005 \%, 0.002 \%$, and $0.002 \%$ increases in inflation, respectively. A $1 \%$ reduction in oil price is related to $0.007 \%, 0.004 \%$, and $0.004 \%$ increases in inflation, respectively. Our results are remarkably similar to the results of $[18,21]$, where both an oil price hike and an oil price plunge were found to be inflationary. In the study [18], positive and negative oil price shocks were found to significantly increase inflation in Iran. A comparison of magnitude was not possible, as the results of [18] were provided as a graph of impulse response functions. The author in [21] investigated the oil and food prices in Malaysia using NARDL and found that food prices increase by $0.0307 \%$ when the oil price increases by $1 \%$, and food prices increase by $0.0216 \%$ when the oil price decreases by $1 \%$. The magnitude of both the positive and negative oil price shocks in [21] was larger than the coefficients found in the present study, i.e., 0.005 and 0.007 , respectively. 
The nonlinear impact of the oil price on inflation is higher when the oil price drops. Therefore, the results indicate that a country's oil price has a higher impact on its level of inflation. However, the results show that it is preferable to use an individual country's oil price, since every country has a different oil price. In Models 2 and 3, for which a global oil price was used, the impacts were found to be the same as when using OPEC and OP, since no difference exists between the countries. The results also revealed that food production had a negative effect on inflation, as an increase in domestic food production reduces the rate of inflation in all models.

Furthermore, it was shown that a $1 \%$ increase in food production is associated with a $0.78 \%, 1.17 \%$, and $1.17 \%$ reduction in inflation in the long run in the three proxies of oil prices, OPC, OPEC, and OP, respectively. The results revealed that, when the OPEC and OP oil price proxies are used, the impact of food production on inflation becomes high. The results also revealed that depreciation in the exchange rate increases inflation. This observation is in line with the actual situation in African OPEC member countries. Moreover, all of the control variables in the nonlinear models maintained the same sign as in the linear models. The money supply, exchange rate, and gross domestic product have a positive sign, while food production has a negative sign. The coefficient values of the error-correction term from the three models are negative, less than 1 , and are a significant indication that there is evidence of convergence toward the equilibrium in the long term.

Table 4. Results from the nonlinear pooled mean group (PMG) and mean group (MG) estimators of oil price.

\begin{tabular}{|c|c|c|c|c|c|c|}
\hline \multirow{2}{*}{$\begin{array}{c}\text { Model } \\
\text { Long Term }\end{array}$} & \multicolumn{2}{|c|}{ Model 1} & \multicolumn{2}{|c|}{ Model 2} & \multicolumn{2}{|c|}{ Model 3} \\
\hline & PMG & MG & PMG & MG & PMG & MG \\
\hline $\mathrm{OPC}+$ & $\begin{array}{c}0.005^{* * *} \\
(4.08)\end{array}$ & $\begin{array}{l}0.002 \\
(1.32) \\
\end{array}$ & - & - & - & - \\
\hline OPC- & $\begin{array}{c}0.007^{* *} \\
(2.18)\end{array}$ & $\begin{array}{l}0.002 \\
(0.90)\end{array}$ & - & - & - & - \\
\hline OPEC+ & - & - & $\begin{array}{c}0.02^{* * *} \\
(3.79)\end{array}$ & $\begin{array}{l}0.007 \\
(1.12)\end{array}$ & - & - \\
\hline OPEC- & - & - & $\begin{array}{l}0.04^{* *} \\
(2.18)\end{array}$ & $\begin{array}{l}0.017 \\
(0.84)\end{array}$ & - & - \\
\hline $\mathrm{OP}+$ & - & - & - & - & $\begin{array}{c}0.02 * * * \\
(3.79)\end{array}$ & $\begin{array}{l}0.007 \\
(1.12)\end{array}$ \\
\hline OP- & - & - & - & - & $\begin{array}{c}0.04^{* *} \\
(2.18)\end{array}$ & $\begin{array}{l}0.017 \\
(0.84)\end{array}$ \\
\hline LM2 & $\begin{array}{c}0.50^{* * *} \\
(6.39)\end{array}$ & $\begin{array}{c}0.36^{* *} \\
(2.55) \\
\end{array}$ & $\begin{array}{c}0.54^{* * *} \\
(6.30)\end{array}$ & $\begin{array}{c}0.34^{* * *} \\
(2.71)\end{array}$ & $\begin{array}{c}0.54 * * * \\
(6.30)\end{array}$ & $\begin{array}{c}0.34 \\
(2.71)^{* * *}\end{array}$ \\
\hline LE & $\begin{array}{c}0.34^{* * *} \\
(7.59)\end{array}$ & $\begin{array}{c}0.46^{* * *} \\
(2.69)\end{array}$ & $\begin{array}{c}0.39 * * * \\
(7.60)\end{array}$ & $\begin{array}{c}0.47^{* *} \\
(2.46)\end{array}$ & $\begin{array}{c}0.39 * * * \\
(7.60)\end{array}$ & $\begin{array}{l}0.47^{* *} \\
(2.46)\end{array}$ \\
\hline LFPI & $\begin{array}{l}-0.78^{* *} \\
(-2.10)\end{array}$ & $\begin{array}{c}-0.81 \\
(-1.18) \\
\end{array}$ & $\begin{array}{c}-1.17^{* * *} \\
(-2.76)\end{array}$ & $\begin{array}{c}-0.80 \\
(-1.12)\end{array}$ & $\begin{array}{c}-1.17^{* * *} \\
(-2.76)\end{array}$ & $\begin{array}{c}-0.80 \\
(-1.12)\end{array}$ \\
\hline LGDP & $\begin{array}{c}0.48^{* * *} \\
(9.14)\end{array}$ & $\begin{array}{c}0.42^{* * *} \\
(4.56)\end{array}$ & $\begin{array}{c}0.51^{* * *} \\
(8.84)\end{array}$ & $\begin{array}{c}0.38^{* * *} \\
(4.26)\end{array}$ & $\begin{array}{c}0.51^{* * *} \\
(8.84)\end{array}$ & $\begin{array}{c}0.38^{* * *} \\
(4.26)\end{array}$ \\
\hline ECT & $\begin{array}{l}-0.23^{* * *} \\
(-3.22)\end{array}$ & $\begin{array}{l}-0.007 \\
(0.001)\end{array}$ & $\begin{array}{l}-0.21^{* * *} \\
(-2.65)\end{array}$ & $\begin{array}{c}0.02 \\
(0.05)\end{array}$ & $\begin{array}{c}-0.21^{* * *} \\
(-2.65)\end{array}$ & $\begin{array}{c}0.02 \\
(0.05)\end{array}$ \\
\hline
\end{tabular}


Table 4. Cont.

\begin{tabular}{|c|c|c|c|c|c|c|}
\hline \multirow{2}{*}{$\begin{array}{c}\text { Model } \\
\text { Short Term }\end{array}$} & \multicolumn{2}{|c|}{ Model 1} & \multicolumn{2}{|c|}{ Model 2} & \multicolumn{2}{|c|}{ Model 3} \\
\hline & PMG & MG & PMG & MG & PMG & MG \\
\hline $\mathrm{OP}+$ & $\begin{array}{c}0.001^{* * *} \\
(2.63)\end{array}$ & $\begin{array}{l}0.004 \\
(0.65)\end{array}$ & $\begin{array}{l}0.01^{* *} \\
(2.48)\end{array}$ & $\begin{array}{l}-0.001 \\
(-0.30)\end{array}$ & $\begin{array}{c}0.01^{* *} \\
(2.48)\end{array}$ & $\begin{array}{l}-0.001 \\
(-0.30)\end{array}$ \\
\hline OP- & $\begin{array}{l}-0.004 \\
(-0.85)\end{array}$ & $\begin{array}{l}0.009 \\
(1.07)\end{array}$ & $\begin{array}{c}-0.02 \\
(-0.89)\end{array}$ & $\begin{array}{l}0.001 \\
(0.16)\end{array}$ & $\begin{array}{c}-0.02 \\
(-0.89)\end{array}$ & $\begin{array}{l}0.001 \\
(0.16)\end{array}$ \\
\hline LM2 & $\begin{array}{c}0.01 \\
(0.25) \\
\end{array}$ & $\begin{array}{c}0.01 \\
(0.29) \\
\end{array}$ & $\begin{array}{c}0.02 \\
(0.33)\end{array}$ & $\begin{array}{c}0.02 \\
(0.42) \\
\end{array}$ & $\begin{array}{c}0.02 \\
(0.33)\end{array}$ & $\begin{array}{c}0.02 \\
(0.42) \\
\end{array}$ \\
\hline LE & $\begin{array}{c}-0.03 \\
(-0.33)\end{array}$ & $\begin{array}{c}0.17 \\
(1.61)\end{array}$ & $\begin{array}{l}0.003 \\
(0.04)\end{array}$ & $\begin{array}{c}0.18 \\
(1.64)\end{array}$ & $\begin{array}{l}0.003 \\
(0.04)\end{array}$ & $\begin{array}{c}0.18 \\
(1.64)\end{array}$ \\
\hline LFPI & $\begin{array}{c}-0.03 \\
(-1.33)\end{array}$ & $\begin{array}{c}-0.01 \\
(-0.59)\end{array}$ & $\begin{array}{c}-0.01 \\
(-0.64)\end{array}$ & $\begin{array}{c}-0.01 \\
(-0.48)\end{array}$ & $\begin{array}{c}-0.01 \\
(-0.64)\end{array}$ & $\begin{array}{c}-0.01 \\
(-0.48)\end{array}$ \\
\hline LGDP & $\begin{array}{c}0.13 \\
(1.47)\end{array}$ & $\begin{array}{c}0.02 \\
(0.30)\end{array}$ & $\begin{array}{c}0.13 \\
(1.56)\end{array}$ & $\begin{array}{c}0.02 \\
(0.40)\end{array}$ & $\begin{array}{c}0.13 \\
(1.56)\end{array}$ & $\begin{array}{c}0.02 \\
(0.40)\end{array}$ \\
\hline Cons & $\begin{array}{c}0.02 \\
(0.19)\end{array}$ & $\begin{array}{c}2.26 \\
(1.27)\end{array}$ & $\begin{array}{l}0.28^{*} \\
(1.78)\end{array}$ & $\begin{array}{c}2.26 \\
(1.35)\end{array}$ & $\begin{array}{l}0.28 * \\
(1.78)\end{array}$ & $\begin{array}{l}2.26 \\
(1.35)\end{array}$ \\
\hline Hausman Test & - & $(0.50)$ & - & $(0.96)$ & - & $(0.96)$ \\
\hline Size $(N \times T)$ & 320 & 320 & 320 & 320 & 320 & 320 \\
\hline
\end{tabular}

To check the robustness of the results in Table 4, it is important to control for the external sources of inflation and compare the results. We re-estimated the results using our final model; that is, the model that uses the particular country's oil price (Model 1) and the PMG estimator by adding the USA GDP, China's GDP, and the global GDP one at a time. The robustness results with the additional external sources of inflation are presented in Table 5. The coefficients for the USA GDP, China's GDP, and the global GDP are negative; however, only the coefficient for the USA GDP is statistically significant. This finding suggests that economic growth in the United States leads to a reduction in price level in these African OPEC member countries. This can be explained as follows: growth in USA GDP due to an increase in productivity leads to a reduction in the general price level in the United States, and, in turn, the African OPEC member countries benefit from cheaper imports from the United States Therefore, the USA GDP negatively influences the price level in the African OPEC member countries. The USA GDP significantly affects the African OPEC member countries but not China because the United States has been the main point of origin of imports for these countries for a few decades as compared to China, which emerged as the main point of origin of imports after 2007. Generally, the results in Table 5 are quite similar to the results in Table 4; in particular, all of the variables carry a similar sign with the exception of OPC- in the robustness check for China's GDP and OPC+ and FPI in the robustness check for global GDP, which became insignificant. 
Table 5. Robustness checks.

\begin{tabular}{|c|c|c|c|}
\hline Model & $\begin{array}{c}\text { Robustness Check } 1 \\
\text { (External Shock: USA } \\
\text { GDP) }\end{array}$ & $\begin{array}{l}\text { Robustness Check } 2 \\
\text { (External Shock: } \\
\text { China's GDP) }\end{array}$ & $\begin{array}{c}\text { Robustness Check } 3 \\
\text { (External Shock: Global } \\
\text { GDP) }\end{array}$ \\
\hline Long Run & PMG & PMG & PMG \\
\hline $\mathrm{OPC}+$ & $\begin{array}{c}0.0035^{* * *} \\
(2.74)\end{array}$ & $\begin{array}{l}0.0051 * * * \\
(3.81)\end{array}$ & $\begin{array}{l}0.0018 \\
(1.25)\end{array}$ \\
\hline OPC- & $\begin{array}{c}0.0121^{* * *} \\
(5.01)\end{array}$ & $\begin{array}{c}0.0031 \\
(0.83)\end{array}$ & $\begin{array}{l}0.01370 * * * \\
(4.44)\end{array}$ \\
\hline LM2 & $\begin{array}{c}0.3064^{* * *} \\
(5.62)\end{array}$ & $\begin{array}{l}0.5241^{* * *} \\
(7.11)\end{array}$ & $\begin{array}{c}0.3553^{* * *} \\
(6.01)\end{array}$ \\
\hline LE & $\begin{array}{l}0.3931^{* * *} \\
\quad(8.47)\end{array}$ & $\begin{array}{c}0.3210^{* * *} \\
(4.99)\end{array}$ & $\begin{array}{c}0.4007^{* * *} \\
(7.00)\end{array}$ \\
\hline LFPI & $\begin{array}{c}-0.2868^{* *} \\
(-2.01)\end{array}$ & $\begin{array}{c}-0.7387 \text { ** } \\
(-1.97)\end{array}$ & $\begin{array}{l}-0.1332 \\
(-0.67)\end{array}$ \\
\hline LGDP & $\begin{array}{c}0.3829 * * * \\
(9.71)\end{array}$ & $\begin{array}{l}0.5131^{* * * *} \\
(9.59)\end{array}$ & $\begin{array}{c}0.3420^{* * *} \\
(6.48)\end{array}$ \\
\hline LGDPUS & $\begin{array}{c}-0.0818^{* * *} \\
(-2.76)\end{array}$ & - & - \\
\hline LGDPChina & - & $\begin{array}{l}-0.0412 \\
(-0.74)\end{array}$ & - \\
\hline LGDPWorld & - & - & $\begin{array}{l}-0.0576 \\
(-1.38)\end{array}$ \\
\hline Error Correction & $\begin{array}{c}-0.2621^{* * *} \\
(-5.69)\end{array}$ & $\begin{array}{c}-0.2429 * * * \\
(-3.03)\end{array}$ & $\begin{array}{c}-0.2577^{* * *} \\
(-4.73)\end{array}$ \\
\hline Short Run & PMG & PMG & PMG \\
\hline $\mathrm{OPC}+$ & $\begin{array}{c}0.0016^{* *} \\
(2.58)\end{array}$ & $\begin{array}{c}0.0022 * * \\
(2.00)\end{array}$ & $\begin{array}{l}0.0015^{* * *} \\
(3.57)\end{array}$ \\
\hline OPC- & $\begin{array}{l}-0.0040 \\
(-0.68)\end{array}$ & $\begin{array}{l}-0.0170 \\
(-0.62)\end{array}$ & $\begin{array}{c}-0.0035 \\
(-0.61)\end{array}$ \\
\hline LM2 & $\begin{array}{l}-0.0245 \\
(-0.36)\end{array}$ & $\begin{array}{l}-0.0320 \\
(-0.51)\end{array}$ & $\begin{array}{l}-0.0475 \\
(-0.35)\end{array}$ \\
\hline LE & $\begin{array}{c}-0.0888 \\
(-0.98)\end{array}$ & $\begin{array}{c}-0.0828 \\
(-0.99)\end{array}$ & $\begin{array}{l}-0.0534 \\
(-0.45)\end{array}$ \\
\hline LFPI & $\begin{array}{l}-0.0159 \\
(-0.74)\end{array}$ & $\begin{array}{c}0.0006 \\
(0.02)\end{array}$ & $\begin{array}{l}-0.0197 \\
(-0.50)\end{array}$ \\
\hline LGDP & $\begin{array}{l}0.1137 \\
(1.20)\end{array}$ & $\begin{array}{c}0.0983 \\
(1.07)\end{array}$ & $\begin{array}{c}0.1250 \\
(0.88)\end{array}$ \\
\hline LGDP & $\begin{array}{l}-0.1946 \\
(-1.59)\end{array}$ & $\begin{array}{l}-0.0036 \\
(-1.54)\end{array}$ & $\begin{array}{l}-0.0203 \\
(-1.01)\end{array}$ \\
\hline Cons & $\begin{array}{l}-0.1946 \\
(-1.59)\end{array}$ & $\begin{array}{l}-0.1997 \\
(-1.57)\end{array}$ & $\begin{array}{c}-0.2812^{* *} \\
(-2.38)\end{array}$ \\
\hline Size $(\mathrm{N} \times \mathrm{T})$ & 320 & 320 & 320 \\
\hline
\end{tabular}

Notes: The figures in parentheses are $t$-statistics values. ${ }^{*}, * *$, and ${ }^{* * *}$ denote the $10 \%, 5 \%$, and $1 \%$ levels of significance, respectively. 


\section{Conclusions and Policy Recommendations}

This study aimed to examine the impact of oil price changes on inflation in African OPEC member countries. Accordingly, the study used a panel of annual data on four African OPEC member countries, namely, Algeria, Angola, Libya, and Nigeria, that ranged from 1995 to 2014. Furthermore, this study used each individual country's spot oil price: Algeria (Saharan Brend), Angola (Girassol), Libya (Ess Sider), and Nigeria (Bonny Light). The Pedroni cointegration test was employed to establish a cointegration relationship between the variables of interest, and the dynamic panel ARDL (PMG and MG) models were used to examine the short- and long-term impact of oil price changes on inflation. In the linear models, it was found that the long-term coefficients of oil price, money supply, exchange rate, and GDP positively affected inflation, while the long-term coefficient of food production adversely influenced inflation.

The linear formulation lacks the power to detect asymmetric behaviour in an oil price; so, this study further estimated the effect of the oil price on inflation using a nonlinear formulation by decomposing the oil price into positive and negative changes. In the nonlinear model, it was found that the positive and negative changes in the oil price encourage inflation, but the impact on inflation is more significant when the oil price drops. Additionally, it was found that expansionary monetary policy and currency devaluation have inflationary effects. This study also found that efficient food production had reduced the rate of inflation in the African OPEC member countries.

An important empirical result of this study is the "asymmetric" oil price shocks to the consumer's price. The asymmetries can be explained by the uniqueness of the African OPEC member countries. As mentioned earlier, the African OPEC member countries are food-scarce countries; more than half of these countries' food is imported. In order to keep the domestic prices and food imports as stable as possible, various intervention policies, such as food stocks and price subsidies, have been implemented. In addition, the retail price of fuel has been subsidized for decades. Although the motives behind such policies may range from overall welfare objectives, such as expanding energy access and protecting poor households' incomes, to economic development objectives, such as fostering industrial growth and smoothing domestic consumption, the stabilization of food and fuel prices makes the price adjustment rigid.

It is also argued that with the aim of achieving self-sufficiency, governments tend to react in a way that promotes a decrease in the prices of agricultural commodities. Strategies that have been developed involve matching a country's agricultural commodity price decreases but not increases. Much of the time, policy-makers are silent or inactive when the agricultural commodity price increases, which creates an asymmetric response.

Besides this, the African OPEC member countries are heavily reliant on oil exports and oil revenue for foreign exchange earnings. When the oil price drops, these countries experience exchange rate depreciation. The depreciation of exchange rates causes imports to become more expensive. During oil price hikes, foreign earnings do increase; however, these countries have to use their foreign earnings to finance the imports of food; hence, their exchange rates do not appreciate much and the imports do not become cheaper. According to [45], the exchange rate pass-through is asymmetric. Exchange rate depreciation has a significant impact on the consumer price index, while appreciation does not. Although the import price is lower during an appreciation in currency, the importers retain the benefits of the appreciation in currency in the form of a higher profit by not reducing the domestic prices of goods and services (which is possible if they are not in competitive markets). However, when there is a depreciation in currency, the importers will pass the increase in import cost through to the consumer by raising the domestic prices of goods and services. 
A rise in oil price raises inflation. However, the inverse relationship is not so straightforward in reality. A reduction in the oil price usually does not lead to a reduction in the price of goods and services. The sources of asymmetries can be explained by the economic, institutional, and political situation of these countries. In this regard, one may argue that the more rigid the institutions, the more pronounced the asymmetries.

Viewed as a whole, we would like to stress the relevance that our empirical results have for policy. The findings of this study can inform how policy-makers steer the policy outlines of African OPEC member countries. First and foremost, the findings from the nonlinear relationship between oil price changes and inflation indicate that $1 \%$ increases and decreases in oil price are related to $0.005 \%$ increases in inflation and $0.007 \%$ increases in inflation, respectively. The increase in domestic consumer prices after negative shocks in the oil price points to the rigidities of downward price adjustments. These price distortions might be the adverse consequences of various subsidies on fuel and food items that these countries have provided for decades. These countries need to seriously consider subsidy reform, which can reduce ineffciencies and production costs. It is worth noting that Nigeria started a subsidy removal program in 2012 and Angola started a subsidy removal program in 2017.

The finding that an increase in food production reduces the inflation rate deserves special attention. As mentioned earlier, the African OPEC member countries are food-scarce countries. So, each country's government should build a domestic food production capacity that will decrease the country's dependence on imported food. Each government should encourage domestic food production both in quantity and quality, since food production is anti-inflationary. Specifically, the agricultural administrators of African countries need to have effective programs available for food production to benefit their economies. The technique of farming through the use of mechanised farming machines will also help to improve food production. Therefore, each government should also support and encourage the private sector to invest in and expand the agricultural sector.

Other intervention tools that policy-makers can use to combat inflation are monetary policy and exchange rate policy. Our findings indicate that the money supply and the exchange rate are positively related to inflation. Therefore, policy-makers can strengthen domestic currency and use contractionary monetary policy to reduce the inflation rate. Inflation occurs when an economy grows due to increased spending. When this happens, prices rise and the currency within the economy is worth less than it was before. The depreciation of the exchange rate causes imports to become more expensive and exports to become cheaper. In the context of African OPEC member countries, the price of imported goods will increase because they are more expensive to buy from abroad. However, these countries will not benefit from an increase in exports because the currency depreciation will not influence the price of oil exports that is determined by OPEC; therefore, it cannot make exports more attractive.

Author Contributions: U.B. and L.C. conceived of and designed the research framework. U.B. collected the data and conducted the analysis. The original draft was prepared by U.B.; L.C. revised the paper. Both authors have read and approved the final manuscript.

Funding: This research received no external funding.

Conflicts of Interest: The authors declare no conflict of interest. 


\section{Appendix A}

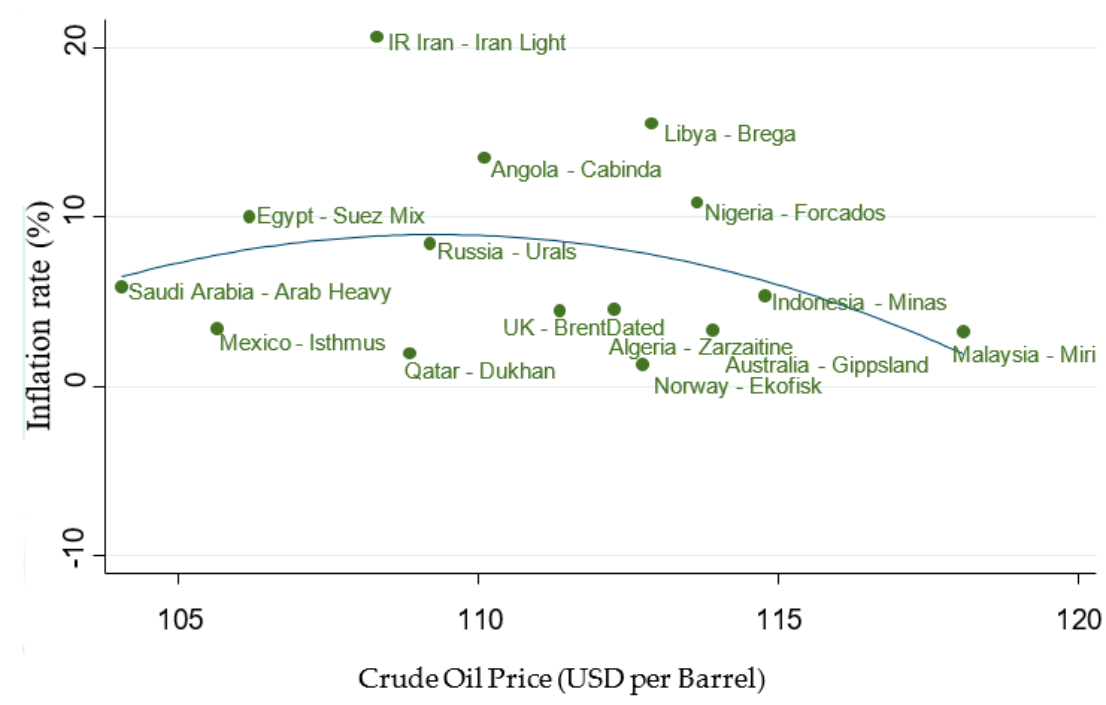

Figure A1. The crude oil price and inflation rates in oil-exporting countries (excluding the United States). Notes: The curve was the best-fit curve to the scatter plot. The shaded area displays the $95 \%$ confidence intervals. Source: This graph was plotted by the first author based on the data reported in the OPEC Annual Statistical Report [8] using the Stata Statistical Software Release 13 (StataCorp LP, TX, USA).

Table A1. Descriptive statisitcs.

\begin{tabular}{|c|c|c|c|c|c|}
\hline & able & Mean & Std. Dev. & Min & Max \\
\hline \multirow{3}{*}{ CPI } & Overall & 74.9837 & 38.0718 & 0.0006 & 146.0394 \\
\hline & Between & - & 19.4111 & 53.4242 & 96.8450 \\
\hline & Within & - & 34.1070 & 21.5602 & 167.5989 \\
\hline \multirow{3}{*}{$\mathrm{OPC}$} & Overall & 54.8368 & 35.6944 & 12.2800 & 114.1500 \\
\hline & Between & - & 0.8666 & 53.9565 & 55.8295 \\
\hline & Within & - & 35.6864 & 11.7773 & 113.1574 \\
\hline \multirow{3}{*}{ OPEC } & Overall & 52.8825 & 34.32606 & 12.28 & 109.45 \\
\hline & Between & - & 0 & 52.8825 & 52.8825 \\
\hline & Within & - & 34.32606 & 12.28 & 109.45 \\
\hline \multirow{3}{*}{ OP } & Overall & 53.3972 & 33.58019 & 13.07667 & 105.0125 \\
\hline & Between & - & 0 & 53.39722 & 53.39722 \\
\hline & Within & - & 33.58019 & 13.07667 & 105.0125 \\
\hline \multirow{3}{*}{ FPI } & Overall & 100.5181 & 32.0088 & 46.0700 & 213.3900 \\
\hline & Between & - & 7.4388 & 91.6992 & 109.5935 \\
\hline & Within & - & 31.3454 & 36.9945 & 204.3146 \\
\hline \multirow{3}{*}{ E } & Overall & 59.2915 & 50.3602 & 0.0027 & 158.5526 \\
\hline & Between & - & 45.2360 & 0.9945 & 110.3545 \\
\hline & Within & - & 31.3369 & -29.1785 & 107.4897 \\
\hline \multirow{3}{*}{ M2 } & Overall & 40.7900 & 23.9209 & 13.2307 & 131.7197 \\
\hline & Between & - & 19.2011 & 22.1446 & 57.8042 \\
\hline & Within & - & 17.0938 & 8.9813 & 114.7056 \\
\hline \multirow{3}{*}{ GDP } & Overall & $95,851.01$ & 110,624 & 4670 & 561600 \\
\hline & Between & - & $62,940.88$ & $46,625.75$ & 178,607 \\
\hline & Within & - & $96,067.12$ & $-50,229.99$ & 478,844 \\
\hline
\end{tabular}

Notes: $\mathrm{CPI}=$ consumer price index, OPC $=$ the specific oil price of a country, OPEC $=$ OPEC reference oil price, $\mathrm{OP}=$ average oil price of the Brent, WTI, and Dubai oil price, FPI $=$ food production index, $\mathrm{E}=$ exchange rate, $\mathrm{M} 2=$ money supply, GDP $=$ GDP per capita current. $\mathrm{n}=4, \mathrm{~T}=20$, and $\mathrm{N}=80$. 
Table A2. Linear panel cointegration results.

\begin{tabular}{|c|c|c|c|c|c|c|}
\hline \multirow{3}{*}{$\begin{array}{l}\text { Equation } \\
\text { Assumption }\end{array}$} & \multicolumn{2}{|c|}{ Model 1} & \multicolumn{2}{|c|}{ Model 2} & \multicolumn{2}{|c|}{ Model 3} \\
\hline & \multicolumn{2}{|c|}{$\begin{array}{c}C P I=f(O P C \\
M 2, E, F P I, G D P)\end{array}$} & \multicolumn{2}{|c|}{$\begin{array}{c}C P I=f(O P E C, \\
M 2, E, F P I, G D P)\end{array}$} & \multicolumn{2}{|c|}{$\begin{array}{c}C P I=f(O P \\
M 2, E, F P I, G D P)\end{array}$} \\
\hline & $\mathrm{w} / \mathrm{o}$ trend & with trend & $\mathrm{w} / \mathrm{o}$ trend & with trend & $\mathrm{w} / \mathrm{o}$ trend & with trend \\
\hline $\begin{array}{c}\text { Panel } \\
\text { v-statistic }\end{array}$ & $\begin{array}{c}-0.307 \\
(0.62)\end{array}$ & $\begin{array}{l}0.290 \\
(0.38)\end{array}$ & $\begin{array}{l}-0.315 \\
(0.62)\end{array}$ & $\begin{array}{l}0.540 \\
(0.29)\end{array}$ & $\begin{array}{c}-0.415 \\
(0.66)\end{array}$ & $\begin{array}{l}0.290 \\
(0.38)\end{array}$ \\
\hline $\begin{array}{c}\text { Panel } \\
\text { rho-statistic }\end{array}$ & $\begin{array}{l}1.075 \\
(0.85)\end{array}$ & $\begin{array}{l}1.966 \\
(0.97)\end{array}$ & $\begin{array}{l}1.068 \\
(0.85)\end{array}$ & $\begin{array}{l}2.113 \\
(0.98)\end{array}$ & $\begin{array}{l}0.998 \\
(0.84)\end{array}$ & $\begin{array}{l}1.966 \\
(0.97)\end{array}$ \\
\hline $\begin{array}{c}\text { Panel } \\
\text { PP-statistic }\end{array}$ & $\begin{array}{c}-3.41^{* * *} \\
(0.00)\end{array}$ & $\begin{array}{c}-4.251^{* * *} \\
(0.00)\end{array}$ & $\begin{array}{c}-3.36^{* * *} \\
(0.00)\end{array}$ & $\begin{array}{c}-2.971 \text { *** } \\
(0.00)\end{array}$ & $\begin{array}{c}-4.180^{* * * *} \\
(0.00)\end{array}$ & $\begin{array}{c}-4.251 \text { *** } \\
(0.00)\end{array}$ \\
\hline $\begin{array}{c}\text { Panel } \\
\text { ADF-statistic }\end{array}$ & $\begin{array}{l}-1.763 * * \\
(0.03)\end{array}$ & $\begin{array}{c}-4.390^{* * *} \\
(0.00)\end{array}$ & $\begin{array}{c}-3.37 * * * \\
(0.00)\end{array}$ & $\begin{array}{c}-3.793 * * * \\
(0.00)\end{array}$ & $\begin{array}{l}-2.119 * * \\
(0.01)\end{array}$ & $\begin{aligned}- & 4.390 * * * \\
& (0.00)\end{aligned}$ \\
\hline $\begin{array}{c}\text { Group } \\
\text { rho-statistic }\end{array}$ & $\begin{array}{l}1.927 \\
(0.97) \\
\end{array}$ & $\begin{array}{l}2.082 \\
(0.98)\end{array}$ & $\begin{array}{c}2.0714 \\
(0.98)\end{array}$ & $\begin{array}{l}2.187^{* * *} \\
(0.98)\end{array}$ & $\begin{array}{l}1.851 \\
(0.96)\end{array}$ & $\begin{array}{l}2.082 \\
(0.98)\end{array}$ \\
\hline $\begin{array}{c}\text { Group } \\
\text { PP-statistic }\end{array}$ & $\begin{array}{c}-3.19 * * * \\
(0.00)\end{array}$ & $\begin{array}{c}-4.340^{* * *} \\
(0.00)\end{array}$ & $\begin{array}{c}-2.76^{* * *} \\
(0.00)\end{array}$ & $\begin{array}{c}-3.101^{* * *} \\
(0.00)\end{array}$ & $\begin{array}{c}-3.726^{* * *} \\
(0.00)\end{array}$ & $\begin{array}{c}-4.340 * * * \\
(0.00)\end{array}$ \\
\hline $\begin{array}{c}\text { Group } \\
\text { ADF-statistic }\end{array}$ & $\begin{array}{c}-1.508 * \\
(0.06)\end{array}$ & $\begin{array}{c}-3.107^{* * *} \\
(0.00)\end{array}$ & $\begin{array}{c}-2.093 * * \\
(0.01)\end{array}$ & $\begin{array}{c}-2.507 * * * \\
(0.00)\end{array}$ & $\begin{array}{l}-1.854^{* *} \\
(0.03)\end{array}$ & $\begin{array}{c}-3.107^{* * *} \\
(0.00)\end{array}$ \\
\hline
\end{tabular}

Notes: the figures in parentheses are the probability values. ${ }^{*}, * *$, and ${ }^{* * *}$ denote the $10 \%, 5 \%$, and $1 \%$ levels of significance, respectively. Number of countries $(N)=4$ and periods $(T)=20$. The maximum numbers of lags were automatically selected using the Akaike information criterion (AIC).

Table A3. The linear PMG and MG results.

\begin{tabular}{|c|c|c|c|c|c|c|}
\hline \multirow{2}{*}{$\begin{array}{c}\text { Model } \\
\text { Long Term }\end{array}$} & \multicolumn{2}{|c|}{ Model 1} & \multicolumn{2}{|c|}{ Model 2} & \multicolumn{2}{|c|}{ Model 3} \\
\hline & PMG & MG & PMG & MG & PMG & MG \\
\hline OPC & $\begin{array}{l}0.34^{* *} \\
(2.39)\end{array}$ & $\begin{array}{c}0.41 \\
(0.89)\end{array}$ & - & - & - & - \\
\hline OPEC & - & - & $\begin{array}{l}0.39 \text { ** } \\
(2.44)\end{array}$ & $\begin{array}{c}0.50 \\
(1.03)\end{array}$ & - & - \\
\hline OP & - & - & - & - & $\begin{array}{c}0.37^{* * *} \\
(2.70)\end{array}$ & $\begin{array}{c}0.37 \\
(0.75)\end{array}$ \\
\hline LM2 & $\begin{array}{c}0.21^{* * *} \\
(2.74)\end{array}$ & $\begin{array}{l}0.43 * \\
(1.92)\end{array}$ & $\begin{array}{c}0.20 * * * \\
(2.61)\end{array}$ & $\begin{array}{l}0.48 * \\
(1.85)\end{array}$ & $\begin{array}{c}0.20 * * * \\
(2.91)\end{array}$ & $\begin{array}{l}0.37 * \\
(1.69)\end{array}$ \\
\hline LE & $\begin{array}{c}0.22 * * * \\
(5.08)\end{array}$ & $\begin{array}{c}-0.10 \\
(-0.25)\end{array}$ & $\begin{array}{c}0.21^{* * *} \\
(5.03)\end{array}$ & $\begin{array}{c}-0.17 \\
(-0.38)\end{array}$ & $\begin{array}{c}0.21^{* * *} \\
(5.63)\end{array}$ & $\begin{array}{c}-0.01 \\
(-0.03)\end{array}$ \\
\hline LFPI & $\begin{array}{l}-1.55^{* * *} \\
(-3.18)\end{array}$ & $\begin{array}{c}-4.19 \\
(-1.00)\end{array}$ & $\begin{array}{l}-1.57^{* * *} \\
(-3.17)\end{array}$ & $\begin{array}{c}-4.75 \\
(-0.99)\end{array}$ & $\begin{array}{l}-1.57^{* * *} \\
(-3.47)\end{array}$ & $\begin{array}{c}-4.27 \\
(-1.04)\end{array}$ \\
\hline LGDP & $\begin{array}{c}0.38^{* * *} \\
(6.40)\end{array}$ & $\begin{array}{l}0.58^{* *} \\
(1.78)\end{array}$ & $\begin{array}{c}0.35^{* * *} \\
(5.08)\end{array}$ & $\begin{array}{c}0.56 \\
(1.24)\end{array}$ & $\begin{array}{c}0.39^{* * *} \\
(7.32)\end{array}$ & $\begin{array}{c}0.70 * * * \\
(2.84)\end{array}$ \\
\hline ECT & $\begin{array}{l}-0.18^{* *} \\
(-2.17)\end{array}$ & $\begin{array}{c}0.05 \\
(0.18)\end{array}$ & $\begin{array}{l}-0.18^{* *} \\
(-2.14)\end{array}$ & $\begin{array}{c}0.05 \\
(0.20)\end{array}$ & $\begin{array}{l}-0.18^{* *} \\
(-2.05)\end{array}$ & $\begin{array}{c}0.02 \\
(0.09)\end{array}$ \\
\hline
\end{tabular}


Table A3. Cont.

\begin{tabular}{|c|c|c|c|c|c|c|}
\hline \multirow{2}{*}{$\begin{array}{c}\text { Model } \\
\text { Short Term }\end{array}$} & \multicolumn{2}{|c|}{ Model 1} & \multicolumn{2}{|c|}{ Model 2} & \multicolumn{2}{|c|}{ Model 3} \\
\hline & PMG & MG & PMG & MG & PMG & MG \\
\hline OPC & $\begin{array}{c}0.22 \\
(1.15)\end{array}$ & $\begin{array}{c}0.07 \\
(0.89)\end{array}$ & - & - & - & - \\
\hline OPEC & - & - & $\begin{array}{c}0.22 \\
(1.15)\end{array}$ & $\begin{array}{c}0.07 \\
(0.93)\end{array}$ & - & - \\
\hline OP & - & - & - & - & $\begin{array}{c}0.21 \\
(1.15) \\
\end{array}$ & $\begin{array}{c}0.09 \\
(1.08)\end{array}$ \\
\hline LM2 & $\begin{array}{l}-0.05 * \\
(-1.83)\end{array}$ & $\begin{array}{l}-0.07^{* *} \\
(-2.33)\end{array}$ & $\begin{array}{l}-0.05 * \\
(-1.85)\end{array}$ & $\begin{array}{l}-0.07^{* *} \\
(-2.64)\end{array}$ & $\begin{array}{l}-0.06^{*} \\
(-1.81)\end{array}$ & $\begin{array}{l}-0.07^{* *} \\
(-2.24)\end{array}$ \\
\hline LE & $\begin{array}{c}-0.06 \\
(-0.84)\end{array}$ & $\begin{array}{c}0.06 \\
(0.68)\end{array}$ & $\begin{array}{c}-0.06 \\
(-0.81)\end{array}$ & $\begin{array}{c}0.06 \\
(0.73)\end{array}$ & $\begin{array}{c}-0.06 \\
(-0.79)\end{array}$ & $\begin{array}{c}0.04 \\
(0.50)\end{array}$ \\
\hline LFPI & $\begin{array}{l}-0.04^{* *} \\
(-2.45)\end{array}$ & $\begin{array}{c}0.02 \\
(0.47)\end{array}$ & $\begin{array}{l}-0.04 * * \\
(-2.43)\end{array}$ & $\begin{array}{c}0.04 \\
(0.55)\end{array}$ & $\begin{array}{l}-0.05^{* *} \\
(-2.45)\end{array}$ & $\begin{array}{c}0.04 \\
(0.55)\end{array}$ \\
\hline LGDP & $\begin{array}{c}-0.14 \\
(-0.81)\end{array}$ & $\begin{array}{c}0.01 \\
(0.37)\end{array}$ & $\begin{array}{c}-0.15 \\
(-0.80)\end{array}$ & $\begin{array}{c}0.02 \\
(0.51)\end{array}$ & $\begin{array}{c}-0.12 \\
(-0.77)\end{array}$ & $\begin{array}{l}-0.005 \\
(-0.12)\end{array}$ \\
\hline Cons & $\begin{array}{c}0.82 \text { *** } \\
(2.65)\end{array}$ & $\begin{array}{l}3.55^{* *} \\
(2.19)\end{array}$ & $\begin{array}{c}0.86 \text { ** } \\
(2.58)\end{array}$ & $\begin{array}{l}3.63^{* *} \\
(2.38)\end{array}$ & $\begin{array}{l}0.85 * * \\
(2.50)\end{array}$ & $\begin{array}{l}3.51 * * \\
(2.02)\end{array}$ \\
\hline Hausman & - & $(0.62)$ & - & $(\mathrm{N})$ & - & $(\mathrm{N})$ \\
\hline Size $(\mathrm{N} \times \mathrm{T})$ & 320 & 320 & 320 & 320 & 320 & 320 \\
\hline
\end{tabular}

Notes: The figures in parentheses are $\mathrm{t}$-statistics values. $\mathrm{N}=$ not supported by the data. ${ }^{*}, * *$, and ${ }^{* * *}$ denote the $10 \%$, $5 \%$, and $1 \%$ levels of significance, respectively.

\section{References}

1. Leblanc, M.; Chinn, M.D. Do High Oil Prices Presage Inflation? The Evidence from G-5 Countries; Department of Economics, UCSC UC: Santa Cruz, CA, USA, 2004.

2. De-Gregorio, J.; Landerretche, O.; Neilson, C. Another pass-through bites the dust? Oil prices and inflation. Economía 2007, 7, 155-196. [CrossRef]

3. Lu, W.; Liu, T.; Tseng, C. Volatility transmissions between shocks to the oil price and inflation: Evidence from a bivariate GARCH approach. J. Inf. Optim. Sci. 2010, 31, 927-939. [CrossRef]

4. Akpan, E.O. Oil resource management and food insecurity in Nigeria. In Proceedings of the European Report on Development (ERD) Conference, Accra, Ghana, 21-23 May 2009; pp. 21-23.

5. Hamilton, J.D. Historical Oil Shocks; NBER Working Papers 16790; National Bureau of Economic Research, Inc.: Cambridge, MA, USA, 2011.

6. Rafiq, S.; Salim, R.; Bloch, H. Impact of crude oil price volatility on economic activities: An empirical investigation in the Thai economy. Resour. Policy 2009, 34, 121-132. [CrossRef]

7. Baffes, J.; Kose, M.A.; Ohnsorge, F.; Stocker, M. The Great Plunge in Oil Prices: Causes, Consequences, and Policy Responses; World Bank Group: Washington, DC, USA, 2015; pp. 1-51.

8. OPEC Annual Statistical Bulletin, Vienna, Austria, 2015. Available online: www.opec.org (accessed on 26 October 2017).

9. Razmi, F.; Azali, M.; Chin, L.; Shah, H.M. The role of monetary transmission channels in transmitting oil price shocks to prices in ASEAN-4 countries during pre- and post-global financial crisis. Energy 2016, 101, 581-591. [CrossRef]

10. Valcarcel, V.J.; Wohar, M.E. Changes in the oil price-inflation pass-through. J. Econ. Bus. 2013, 68, $24-42$. [CrossRef]

11. Gao, L.; Kim, H.; Saba, R. How do oil price shocks affect consumer prices? Energy Econ. 2014, 45, $313-323$. [CrossRef]

12. Xuan, P.P.; Chin, L. Pass-through effect of oil price into consumer price: An Empirical study. Int. J. Econ. Manag. 2015, 9, 143-161. 
13. Kilian, L. Not all oil price shocks are alike: Disentangling demand and supply shocks in the crude oil market. Am. Econ. Rev. 2009, 99, 1053-1069. [CrossRef]

14. Hooker, M. Are oil shocks inflationary? Asymmetric and nonlinear specifications versus changes in regime. J. Money Credit Bank. 2002, 34, 540-561. [CrossRef]

15. Basnet, H.C.; Upadhyaya, K.P. Impact of oil price shocks on output, inflation and the real exchange rate: Evidence from selected ASEAN countries. Appl. Econ. 2015, 47, 3078-3091. [CrossRef]

16. Chou, K.-W.; Lin, P.-C. Oil price shocks and producer prices in Taiwan: An application of non-linear error-correction models. J. Chin. Econ. Bus. Stud. 2013, 11, 59-72. [CrossRef]

17. Lamotte, O.; Porcher, T.; Schalck, C.; Silvestre, S. Asymmetric gasoline price responses in France. Appl. Econ. Lett. 2013, 20, 457-461. [CrossRef]

18. Farzanegan, M.R.; Markwardt, G. The effects of oil price shocks on the Iranian economy. Energy Econ. 2009, 31, 134-151. [CrossRef]

19. Ghosh, S.; Kanjilal, K. Oil price shocks on Indian economy: Evidence from Toda Yamamoto and Markov regime-switching VAR. Macroecon. Financ. Emerg. Mark. Econ. 2013, 7, 122-139. [CrossRef]

20. Çat, A.N.; Önder, A.Ö. An asymmetric analysis of the relationship between oil prices and output: The case of Turkey. Econ. Model. 2013, 33, 884-892. [CrossRef]

21. Ibrahim, M.H. Oil and food prices in Malaysia: A nonlinear ARDL analysis. Agric. Food Econ. 2015, 3, 1-14. [CrossRef]

22. Belke, A.; Dreger, C. The Transmission of oil and food prices to consumer prices: Evidence for the MENA countries. Int. Econ. Econ. Policy 2015, 12, 143-161. [CrossRef]

23. Ianchovichina, E.; Loening, J.; Wood, C. How Vulnerable Are Arab Countries to Global Food Price Shocks? World Bank Policy Research Working Paper 6018; World Bank: Washington, DC, USA, 2015.

24. Belke, A.; Awad, J. On the pass-through of food prices to local inflation in MENA countries. WSEAS Trans. Bus. Econ. 2014, 38, 307-316.

25. Ferrucci, G.; Jiménez-Rodríguez, R.; Onorante, L. Food Price Pass-Through in the Euro Area: The Role of Asymmetries and Non-Linearities; ECB Working Paper No. 1168; European Central Bank: Frankfurt/Main, Germany, 2010.

26. IMF. Is inflation back? Commodity prices and inflation. In World Economic Outlook: Financial Stress, Downturns and Recoveries; International Monetary Fund: Washington DC, USA, 2008; pp. 83-128.

27. Kofi, P.A.; Zumah, F.; Mubarik, A.W.; Ntodi, B.N.; Darko, C.N. Analysing inflation dynamics in Ghana. Afr. Dev. Rev. 2015, 27, 1-13.

28. Bala, U.; Chin, L.; Ranjanee, S.; Ismail, N.W. The Impacts of oil export and food production on inflation in African OPEC members. Int. J. Econ. Manag. 2017, 11, 573-590.

29. Ratti, R.A.; Vespignani, J.L. Oil prices and global factor macroeconomic variables. Energy Econ. 2016, 59, 198-212. [CrossRef]

30. Balke, N.S.; Brown, S.P.A.; Yucel, M.K. Oil price shocks and the U.S. economy: Where does the asymmetry originate? Energy J. 2002, 23, 27-52. [CrossRef]

31. Tang, W.; Wu, L.; Zhang, Z. Oil price shocks and their short- and long-term effects on the Chinese economy. Energy Econ. 2010, 32, 3-14. [CrossRef]

32. Dillon, B.M.; Barrett, C.B. Global oil prices and local food prices: Evidence from East Africa. Am. J. Agric. Econ. 2016, 98, 154-171. [CrossRef]

33. Brown, S.P.A.; Yucel, M.K. Energy prices and aggregate economic activity: An interpretative survey. Q. Rev. Econ. Financ. 2002, 42, 193-208. [CrossRef]

34. Shin, Y.; Yu, B.; Greenwood-Nimmo, M. Modelling asymmetric cointegration and dynamic multipliers in a nonlinear ARDL framework. In Festschrift in Honor of Peter Schmidt; Springer: New York, NY, USA, 2014; Volume 44, pp. 1-35. [CrossRef]

35. Pesaran, M.H.; Shin, Y. An autoregressive distributed lag modelling approach to cointegration analysis. In Econometrics and Economic Theory in the 20th Century; Cambridge University Press: Cambridge, UK, 1999; pp. 1-31.

36. Pesaran, M.H.; Shin, Y.; Smith, R.J. Bounds testing approaches to the analysis of level relationships. J. Appl. Econom. 2001, 16, 289-326. [CrossRef]

37. Levin, A.; Lin, C.F.; Chu, C.S.J. Unit root tests in panel data: Asymptotic and finite-sample properties. J. Econom. 2002, 108, 1-24. [CrossRef] 
38. Im, K.S.; Pesaran, M.H.; Shin, Y. Testing for unit roots in heterogeneous panels. J. Econom. 2003, 115, 53-74. [CrossRef]

39. Maddala, G.S.; Wu, S. A comparative study of unit root tests with panel data and a new simple test. Oxf. Bull. Econ. Stat. 1999, 61, 631-652. [CrossRef]

40. Kang, W.; Ratti, R.A.; Vespignani, J.L. Oil price shocks and policy uncertainty: New evidence on the effects of the US and non-US oil production. Energy Econ. 2017, 66, 536-546. [CrossRef]

41. Global Energy Statistical Yearbook 2018. Available online: https://yearbook.enerdata.net/crude-oil/crudeoil-balance-trade-data.html (accessed on 5 September 2018).

42. World Integrated Trade Solution (WITS), World Bank. Available online: https://wits.worldbank.org/about_ wits.html (accessed on 5 September 2018).

43. Belke, A.; Gros, D. A simple model of an oil based global savings glut-The "China factor" and the OPEC Cartel. Int. Econ. Econ. Policy 2014, 11, 413-430. [CrossRef]

44. Pedroni, P. Critical values for cointegration tests in heterogeneous panels with multiple regressors. Oxf. Bull. Econ. Stat. 1999, 61, 653-670. [CrossRef]

45. Bala, U.; Songsiengchai, P.; Chin, L. Asymmetric behavior of exchange rate pass-through in Thailand. Econ. Bull. 2017, 37, 1289-1297.

(C) 2018 by the authors. Licensee MDPI, Basel, Switzerland. This article is an open access article distributed under the terms and conditions of the Creative Commons Attribution (CC BY) license (http://creativecommons.org/licenses/by/4.0/). 